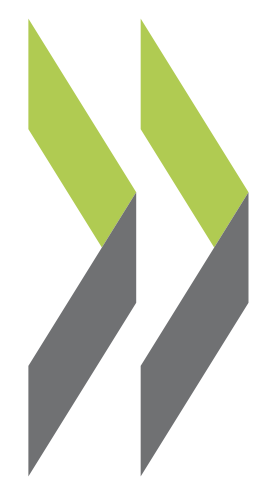

OECD Economics Department Working Papers No. 1183

Challenges

and Opportunities of India's Manufacturing Sector
Isabelle Joumard,

Urban Sila,

Hermes Morgavi 
Organisation de Coopération et de Développement Économiques

Organisation for Economic Co-operation and Development

26-Jan-2015

ECONOMICS DEPARTMENT

English - Or. English

Cancels \& replaces the same document of 08 January 2015

\section{CHALLENGES AND OPPORTUNITIES OF INDIA'S MANUFACTURING SECTOR}

ECONOMICS DEPARTMENT WORKING PAPERS No. 1183

By Isabelle Joumard, Urban Sila and Hermes Morgavi

OECD Working Papers should not be reported as representing the official views of the OECD or of its member countries. The opinions expressed and arguments employed are those of the author(s).

Authorised for publication by Robert Ford, Deputy Director, Country Studies Branch, Economics Department.

Document only available in pdfformat.

All Economics Department Working Papers are available through OECD's Internet website at http://www.oecd.org/eco/workingpapers

\section{JT03369687}

Complete document available on OLIS in its original format

This document and any map included herein are without prejudice to the status of or sovereignty over any territory, to the delimitation of international frontiers and boundaries and to the name of any territory, city or area. 
OECD Working Papers should not be reported as representing the official views of the OECD or of its member countries. The opinions expressed and arguments employed are those of the author(s).

Working Papers describe preliminary results or research in progress by the author(s) and are published to stimulate discussion on a broad range of issues on which the OECD works.

Comments on Working Papers are welcomed, and may be sent to the Economics Department, OECD, 2 rue André-Pascal, 75775 Paris Cedex 16, France, or by e-mail to eco.contact@oecd.org.

This document and any map included herein are without prejudice to the status of or sovereignty over any territory, to the delimitation of international frontiers and boundaries and to the name of any territory, city or area.

The statistical data for Israel are supplied by and under the responsibility of the relevant Israeli authorities. The use of such data by the OECD is without prejudice to the status of the Golan Heights, East Jerusalem and Israeli settlements in the West Bank under the terms of international law.

\section{(C) OECD (2014)}

You can copy, download or print OECD content for your own use, and you can include excerpts from OECD publications, databases and multimedia products in your own documents, presentations, blogs, websites and teaching materials, provided that suitable acknowledgment of OECD as source and copyright owner is given. All requests for commercial use and translation rights should be submitted to rights@oecd.org 


\section{ABSTRACT/RÉSUMÉ \\ Challenges and opportunities of India's manufacturing sector}

The manufacturing sector has contributed little to income growth and its share in total merchandise exports has been declining. Manufacturing has not brought much new employment, and most of the recent rise in manufacturing employment has been in the informal sector, where workers are not covered by social security arrangements.

Productivity of the manufacturing sector is low, partly because the relatively small size of manufacturing firms makes it difficult to exploit economies of scale. Despite abundant, low-skilled and relatively cheap labour, Indian manufacturing is surprisingly capital and skill intensive. Furthermore, firms have little incentive to grow, since by staying small they can avoid taxes and complex labour regulations. Land acquisition is slow, companies face frequent power outages and transport infrastructure is below par. This is especially harmful as manufacturing is highly reliant on well-functioning infrastructure.

Stronger manufacturing would increase productivity and make growth more inclusive, while contributing to improved current account balance. In particular, India should aim for more formal jobs, as these tend to be the most secure and of highest productivity.

This Working Paper relates to the 2014 OECD Economic Survey of India (http://www.oecd.org/eco/surveys/economic-survey-india.htm).

JEL classification: $J 2, J 24, J 46, K 2, L 25, L 26$

Keywords: India, manufacturing, firm size, productivity, employment, informality, labour regulations, education, infrastructure, land acquisition, business environment, taxes, trade facilitation

\section{Défis et opportunités pour le secteur manufacturier en Inde}

Le secteur manufacturier ne contribue guère à l'accroissement du revenu et sa part dans les exportations totales de marchandises diminue, les services étant le premier moteur de la croissance économique. Le secteur crée peu d'emplois et la hausse récente de l'emploi dans la production manufacturière s'est réalisée pour l'essentiel dans le secteur informel, là où les travailleurs ne bénéficient pas de couverture sociale.

La productivité du secteur manufacturier est faible, en partie parce que la taille relativement modeste des entreprises du secteur ne facilite pas les économies d'échelle. En dépit d'une main-d'œuvre abondante, peu qualifiée et relativement bon marché, l'intensité en capital et en emplois qualifiés du secteur manufacturier indien est d'un niveau étonnamment élevé. De surcroît, les entreprises ne sont guère incitées à recruter et à accroître leurs effectifs car en restant de taille modeste, elles évitent les obligations fiscales et une réglementation complexe du travail. Les procédures d'acquisition de terains sont longues, les entreprises sont confrontées à de fréquentes coupures d'électricité et les infrastructures de transport laissent à désirer. Ces facteurs sont d'autant plus dommageables que la production manufacturière est fortement tributaire d'infrastructures qui fonctionnent.

Un secteur manufacturier plus solide permettrait de rehausser la productivité et de rendre la croissance plus inclusive, tout en contribuant à améliorer la balance courante. En particulier, il faudrait que l'Inde vise à créer plus d'emplois formels car ceux-ci offrent généralement le plus de sécurité et sont plus productifs.

Ce document de travail renvoie à l'Étude économique 2014 de l'OCDE sur l'Inde (http://www.oecd.org/fr/eco/etudes/inde.htm).

Classification JEL : J2, J24, J46, K2, L25, L26

Mots clefs: Inde, secteur manufacturier, taille des entreprises, productivité, emploi, règlementation du travail, infrastructure, acquisition du terrain, fiscalité 


\section{TABLE OF CONTENTS}

The manufacturing sector has contributed little to income, export and employment growth .................... 5

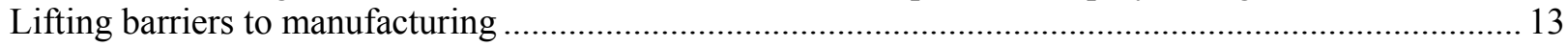

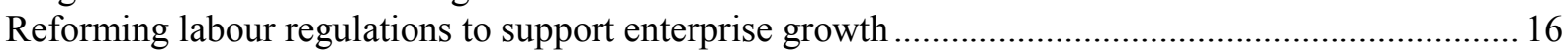

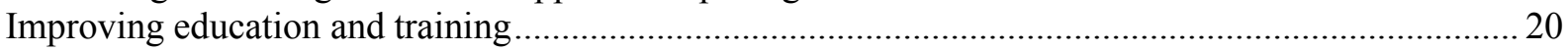

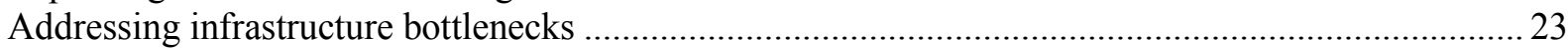

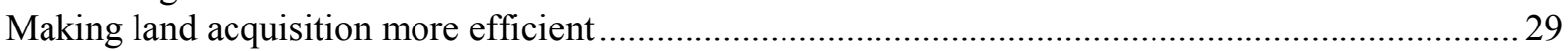

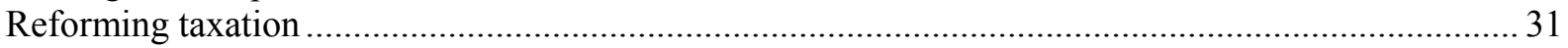

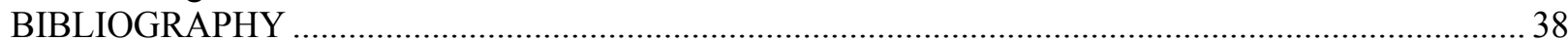

\section{Tables}

1. India has a comparative advantage only in a small number of manufacturing sectors ................... 12

2. Many labour regulations become binding as companies grow ................................................... 17

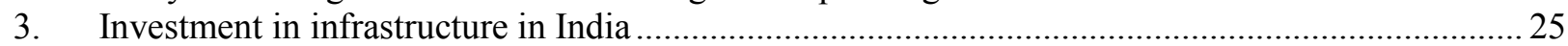

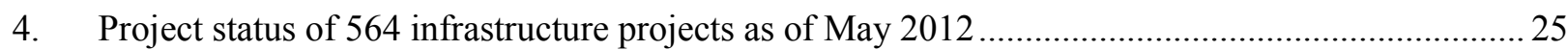

\section{Figures}

1. The manufacturing sector has contributed little to income growth ................................................5

2. Manufacturing productivity is low in international comparisons ................................................ 6

3. Manufacturing firms are small and productivity growth has been low........................................ 8

4. Employment in the manufacturing sector is concentrated in very small firms ............................... 9

5. The manufacturing sector has created few and low quality jobs ................................................. 10

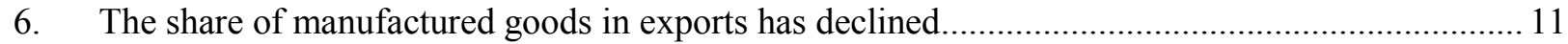

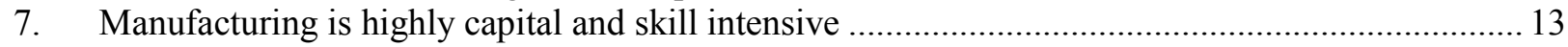

8. Employment protection legislation is highly restrictive .......................................................... 18

9. The average tax wedge on labour is relatively low, especially in small firms ............................. 18

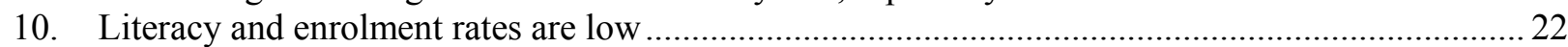

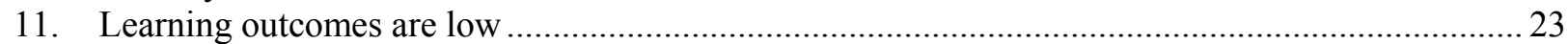

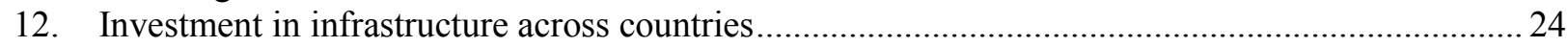

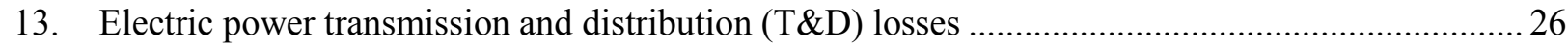

14. Inland freight transport is been overly dominated by roads ........................................................... 28

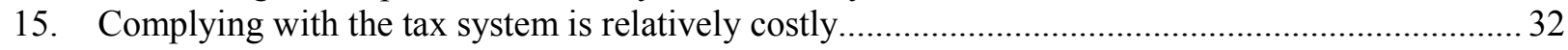

16. OECD indicators on trade facilitation performance show mixed results for India ......................... 35

\section{Boxes}

Box 1. Defining the organised/unorganised and formal/informal sectors in India.............................. 7

Box 2. National Manufacturing Policy (NMP) and the "Make in India" initiative............................. 14

Box 3. Special Economic Zones (SEZs) and National Investment and Manufacturing Zones (NIMZs) 15

Box 4. The Right to Fair Compensation and Transparency in Land Acquisition, Rehabilitation and

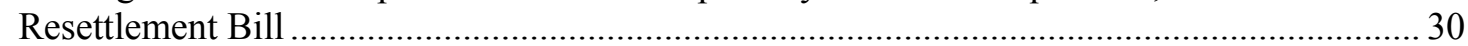

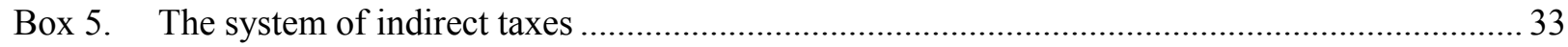

Recommendations to raise employment creation and value added from the manufacturing sector.......... 36 


\title{
Challenges and opportunities of India's manufacturing sector
}

\author{
By Isabelle Joumard, Urban Sila and Hermes Morgavi ${ }^{1}$
}

\section{The manufacturing sector has contributed little to income, export and employment growth}

Production has been shifting away from agriculture, but mostly into services rather than manufacturing. Despite important product market reforms in the early 1990s, such as trade liberalisation and abolition of industrial licensing, the share of manufacturing in GDP has remained stagnant over the past decades (Figure 1, panel A). Economic growth in the last 15 years was led by services (Figure 1, panel B), leaving manufacturing at 13\% of GDP in FY 2013-14 which is low compared to peers (Figure 1, panel C).

Figure 1. The manufacturing sector has contributed little to income growth

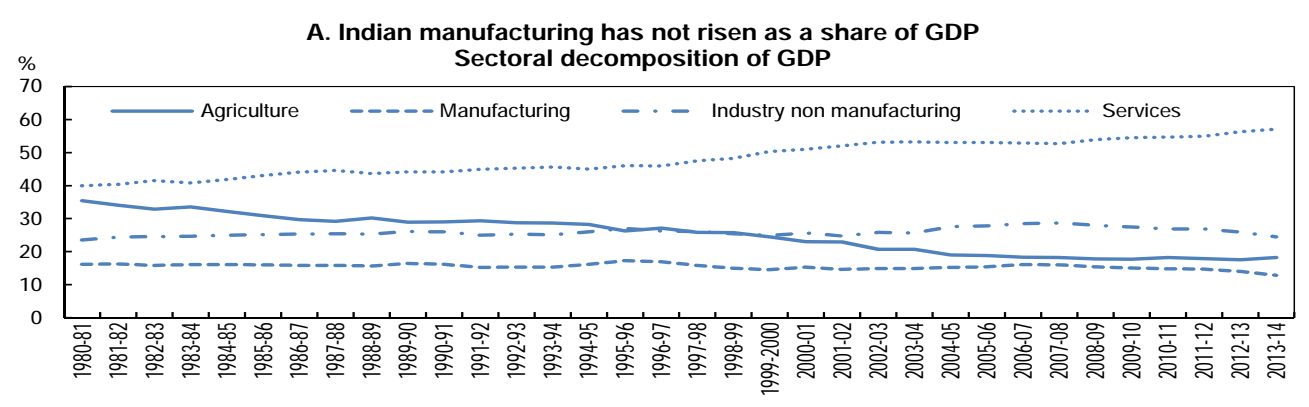

B. Services have contributed the most to economic growth

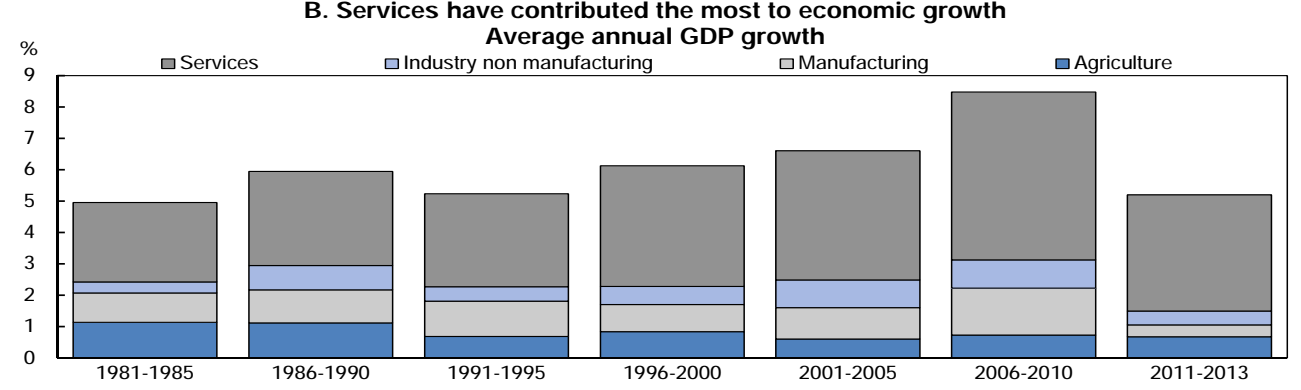

C. The share of manufacturing is low in international comparisons

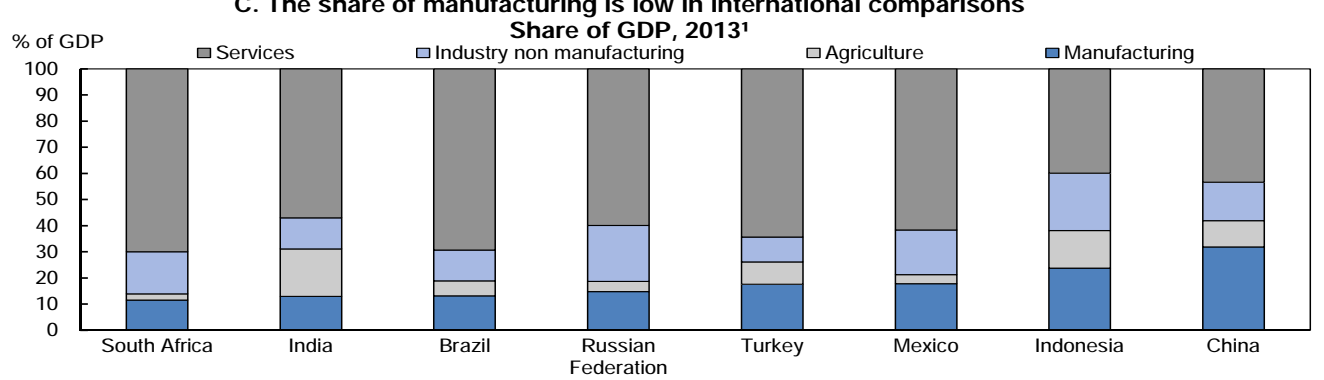

1. Nominal sector share in GDP. Data for China are for year 2011.

2. For India, data are for fiscal year 2013-14.

Source: Indian Central Statistics Office, OECD calculation, and World Development Indicators database.

1. Isabelle Joumard is head of the India Desk in the Economics Department of the OECD; Urban Sila is an economist on the Desk while Hermes Morgavi is a statistician. This paper is based on material prepared for the OECD Economic Survey of India published in November 2014 under the authority of the Economic and Development Review Committee (EDRC). The authors would like to thank Piritta Sorsa, Robert Ford, and Alvaro Pereira for valuable comments on earlier drafts. Special thanks go to Anthony Bolton for excellent editorial support. 
Productivity of the manufacturing sector is low. Drawing cross-country comparisons on productivity requires high quality data and a choice of an appropriate exchange rate for international comparisons. Figure 2 shows the results based on various approaches. They all confirm that the productivity of India's manufacturing sector is lower than in other emerging economies, and also lower than in the service sector. Measured in value added (in PPP) per hour worked, productivity of manufacturing in China and Brazil is 1.6 and 2.9 times higher, respectively, than in India (Figure 2, panel A); the gap in services is significantly smaller.

Figure 2. Manufacturing productivity is low in international comparisons
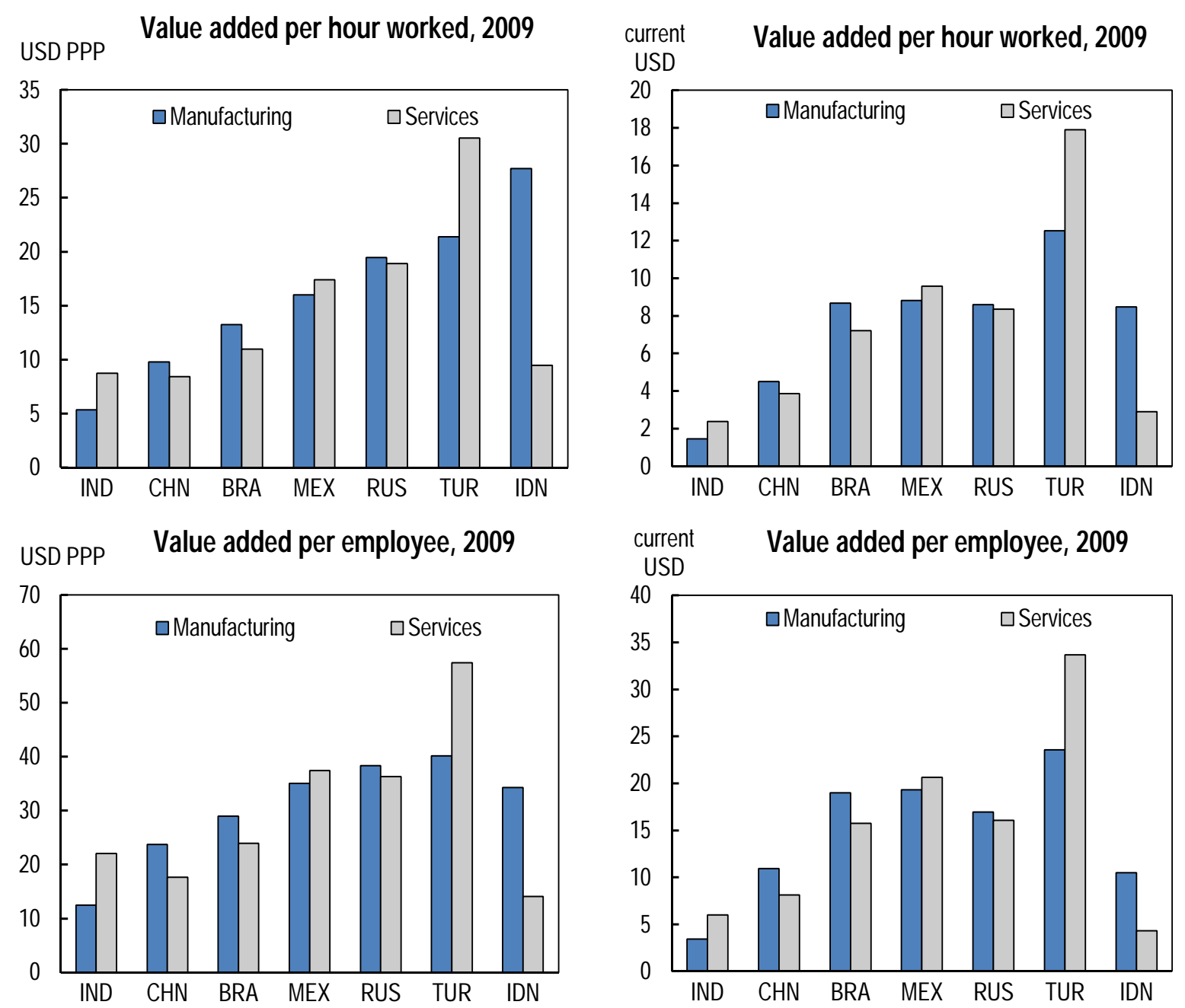

Note: The productivity is measured by gross value added at basic prices divided by the number of hours worked. This measure is then converted in current USD using the PPP conversion factor for GDP.

Source: World Input Output Database and Worldbank WDI database. 
The productivity problem in manufacturing partly stems from the preponderance of small firms with low productivity, which cannot exploit economies of scale (Figure 3). Employment in manufacturing firms with less than 10 employees - the so-called unorganised sector (Box 1) - accounted for about 65\% of employment in the sector in 2011-12, compared to $14 \%$ on average in the OECD and $9 \%$ in Brazil (Figure 4). Even in the organised sector (Box 1), firms have little incentive to grow since by staying small they can avoid regulations and taxes. Growth in total factor productivity in the manufacturing sectors has been lower than in the service sector (RBI, 2014 and Figure 3). In fact, the growth in manufacturing TFP has been negative in many subsectors over the past three decades (Das et al., 2014). In addition, growth of value added in the manufacturing sector largely stems from factor accumulation, in particular increases in capital intensity, rather than total factor productivity gains.

\section{Box 1. Defining the organised/unorganised and formal/informal sectors in India}

The unorganised sector consists of all incorporated private enterprises owned by individuals or households engaged in the sale and production of goods and services operated on a proprietary or partnership basis and with less than ten workers (or twenty if not using electricity).

The organised sector consists of all public sector enterprises and all private sector enterprises with more than 10 workers (more than 20 if not using electricity).

Informal workers consist of those working in the unorganised sector or households, excluding regular workers with social security benefits, and the workers in the organised sector without social security benefits. Contract workers in the organised sector are not covered by social insurance systems and thus count as informal workers.

Formal workers are workers working in the organised or unorganised sector entitled to social security benefits. 
Figure 3. Manufacturing firms are small and productivity growth has been low

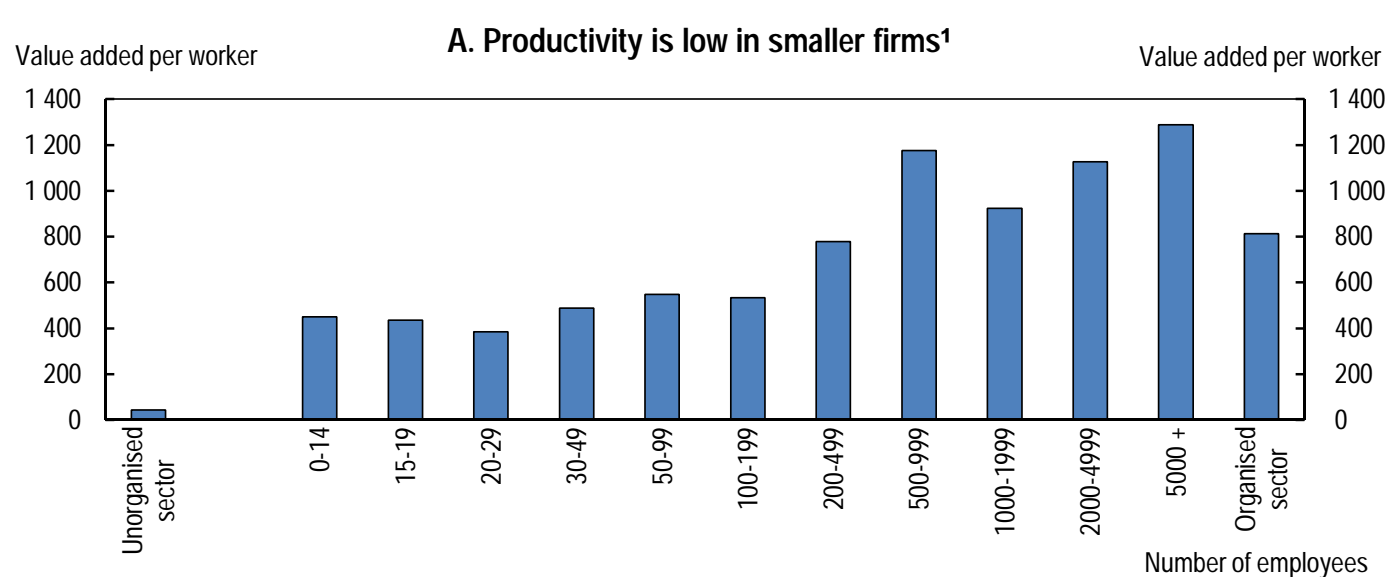

B. Productivity gains have been negative in some manufacturing subsectors over the period $1980-81$ to $2011-12$

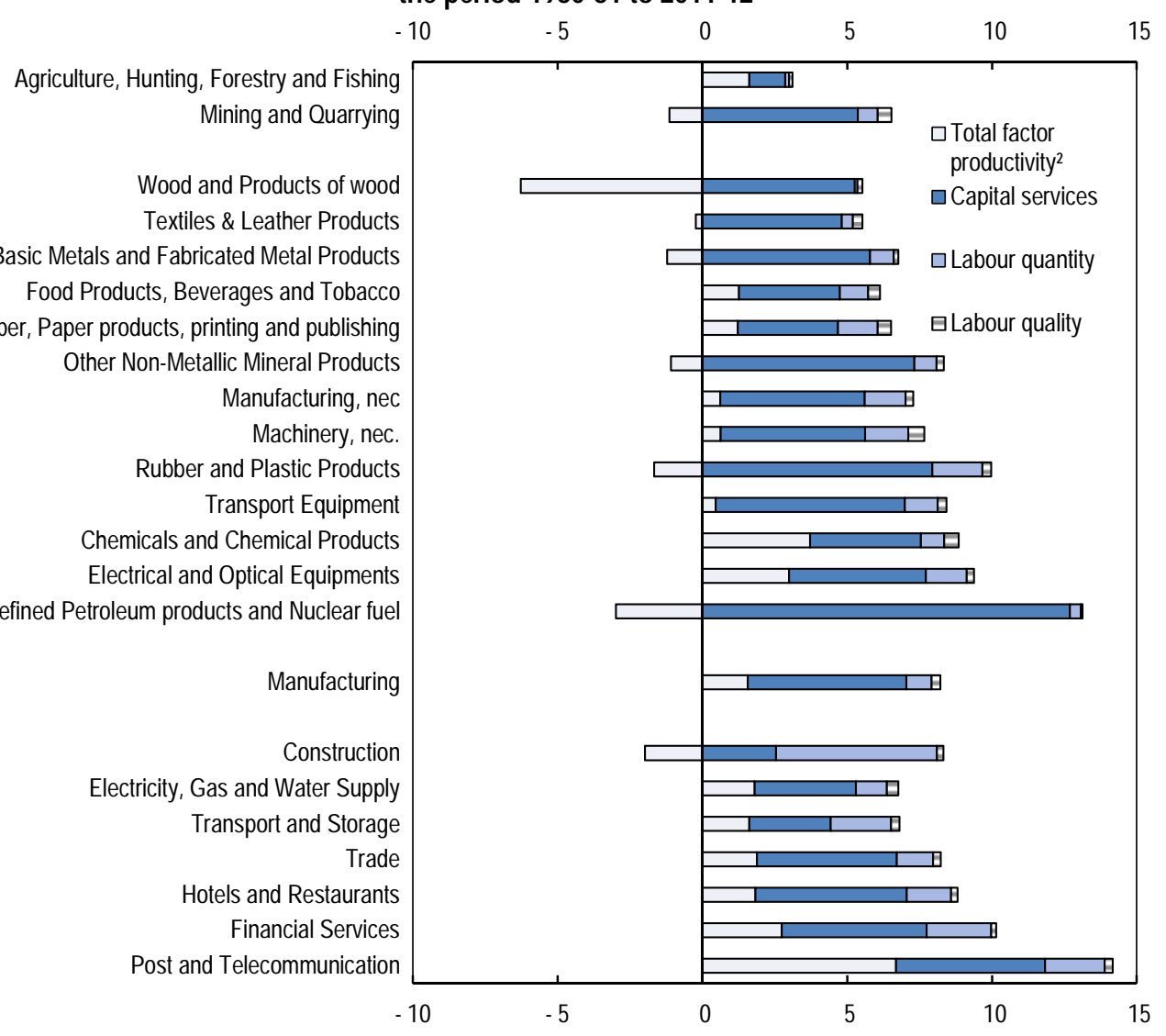

1. The productivity of labour is measured in terms of value added per worker. Value added is measured in rupees.

2. The total factor productivity growth represents the technical change. It is estimated as a residual of the value-added growth not explained by the changes in the quantity and quality of both labour and capital.

Source: ASI 2010-2011 Summary results for the Organised sector, Key Results of Survey on Unincorporated Non-agricultural Enterprises (excluding construction) in India (2010-2011), and Das et al. (2014). 
Figure 4. Employment in the manufacturing sector is concentrated in very small firms

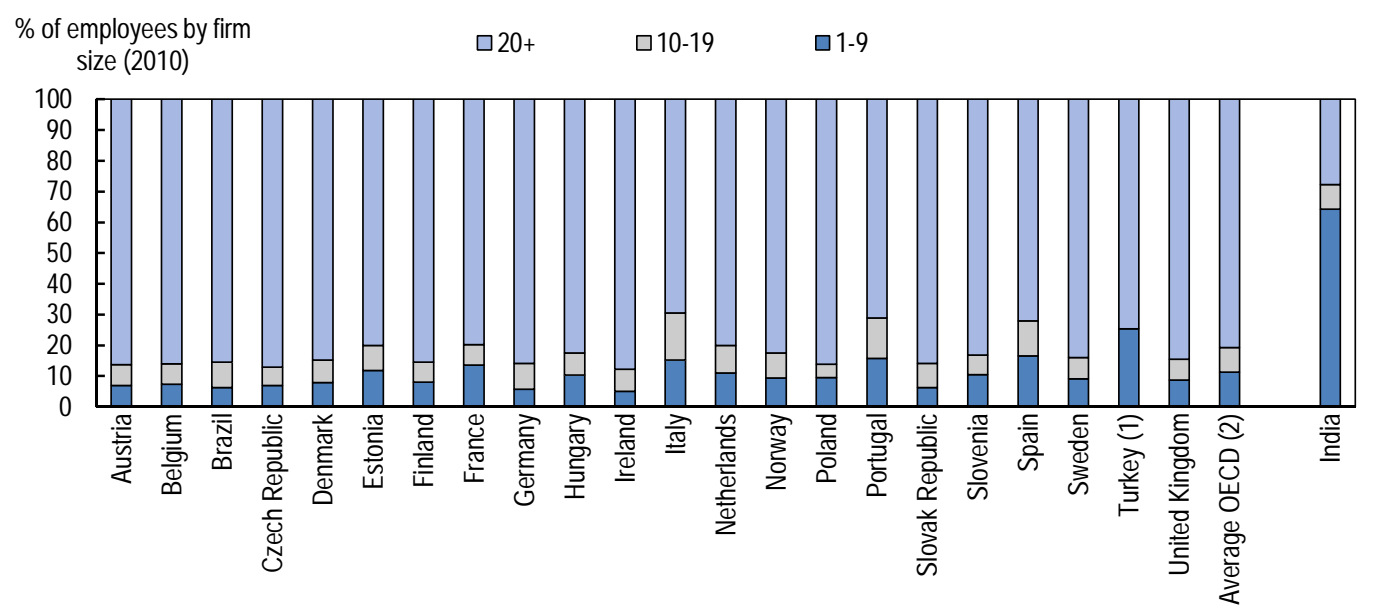

For reasons of comparison, the aggregate "Total employment - number of persons engaged in the production" was chosen. This includes: i) paid employees; ii) employers and self-employed; iii) unpaid family workers.

1. For Turkey, data are for 2009.

2. Simple average.

Source: OECD database for OECD countries and Brazil, NSSO for India.

Total employment outside of agriculture rose by about 51 million between 2004-05 and 2011-12, but only 6 million jobs were created in the manufacturing sector (Figure 5). Moreover, most of them were informal labour (i.e. not covered by social security arrangements).

The share of manufactured goods in total merchandise exports fell from $77 \%$ in 2003 to $65 \%$ in 2013 (Figure 6). India's share in world manufacturing export stood at $1.7 \%$ in 2010 compared to $14 \%$ for China (UNIDO, 2013). The latest competitive industrial performance index ranks India 43nd out of 133 countries, far behind China, but also behind Thailand, Brazil and Indonesia. Nevertheless, the share of medium and high-tech manufactured exports in total manufactured exports increased from $19 \%$ to $28 \%$ between 2000 and 2010, levels similar to Indonesia, but behind Brazil, South Africa and the Philippines (UNIDO, 2013). 
Figure 5. The manufacturing sector has created few and low quality jobs

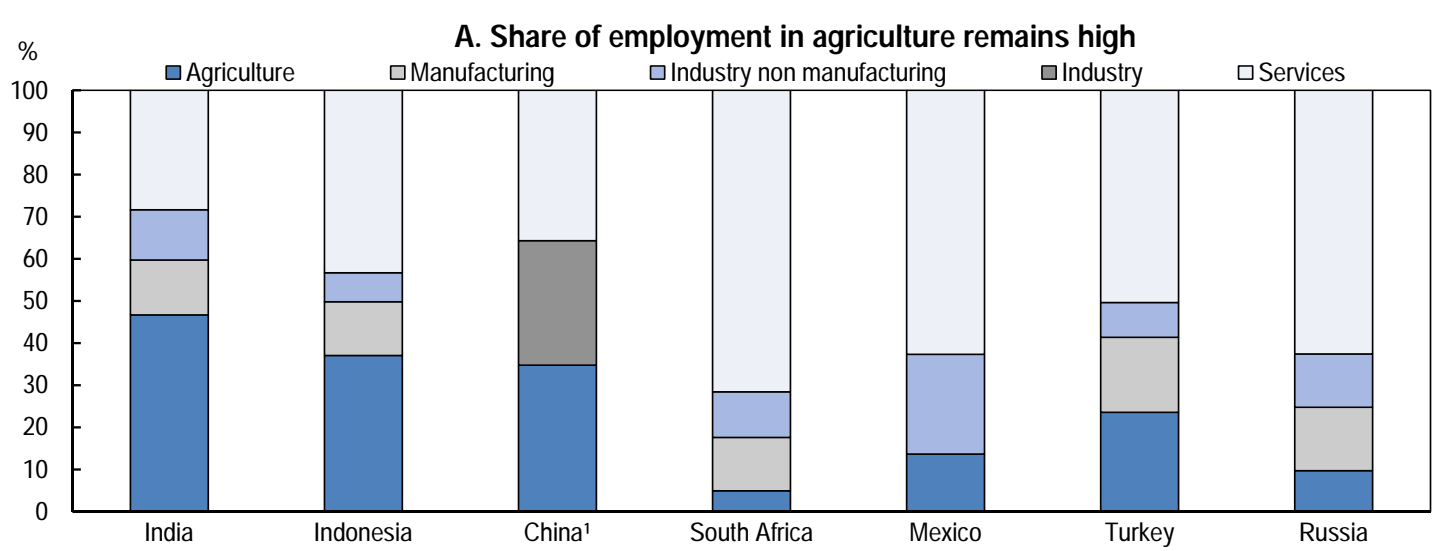

Change in millions $\quad$ B. Employment creation ${ }^{2}$ in the manufacturing sector has been low, 2005-12

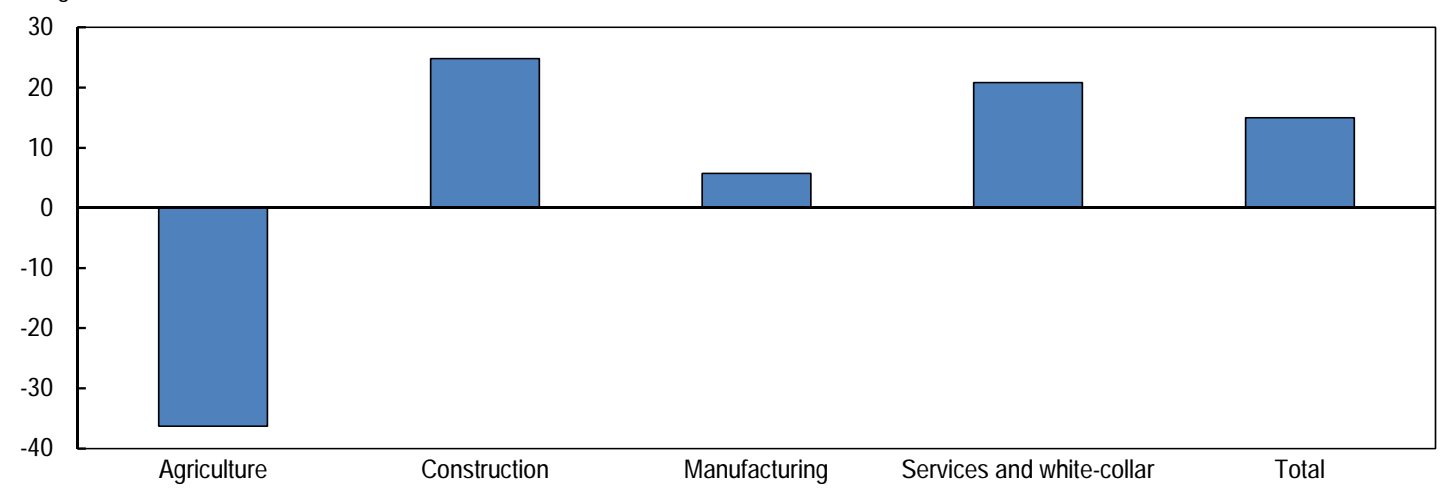

Change in millions

C. Most manufacturing jobs created over the period 2005-12 were informal ${ }^{3}$

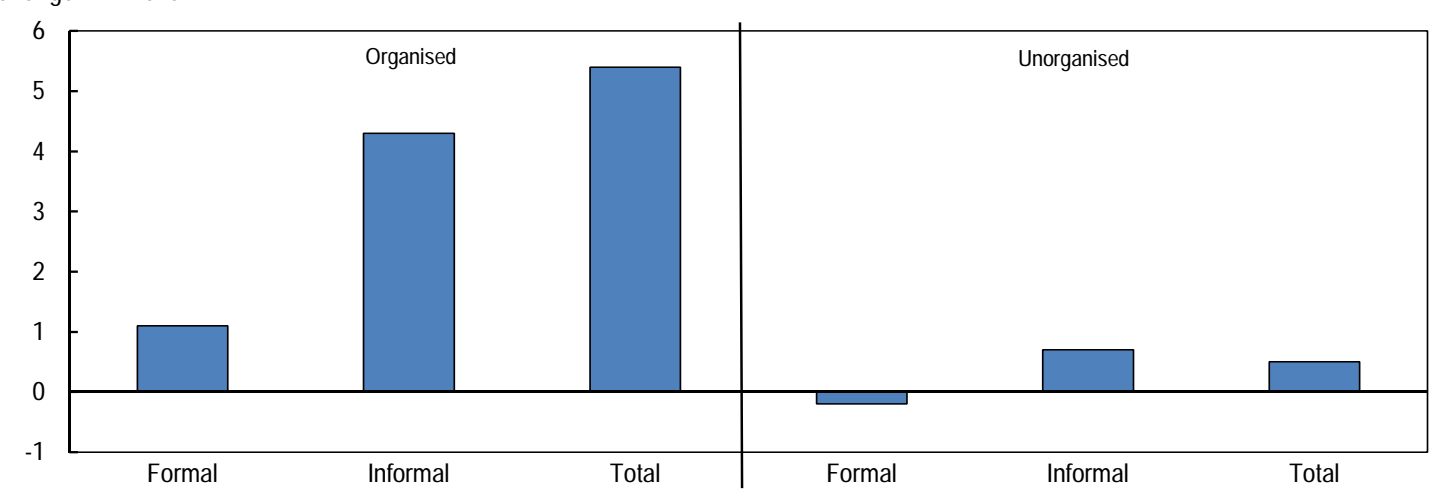

1. For China, data refers to year 2011, for India, to fiscal year 2011-12. Data on the manufacturing sector are not available for China.

2. Employment is based on usual principal and subsidiary status. The principal activity status is the activity (not necessarily an economic one) on which a person spends a relatively longer time during the 365 days preceding the date of survey. The subsidiary economic activity status corresponds to the situation where the person is engaged in an additional economic activity for at least 30 days. Note, that a person who does not work in the principal status could be considered as working according to the usual principal and subsidiary status.

3. Informal workers are those with no social security benefits (Mehrotra et al., 2014).

Source: OECD Labour market statistics, NSSO, Employment and unemployment survey, rounds no. 61 and 68 , National Bureau of statistics of China, and Mehrotra et al. (2014). 
Figure 6. The share of manufactured goods in exports has declined

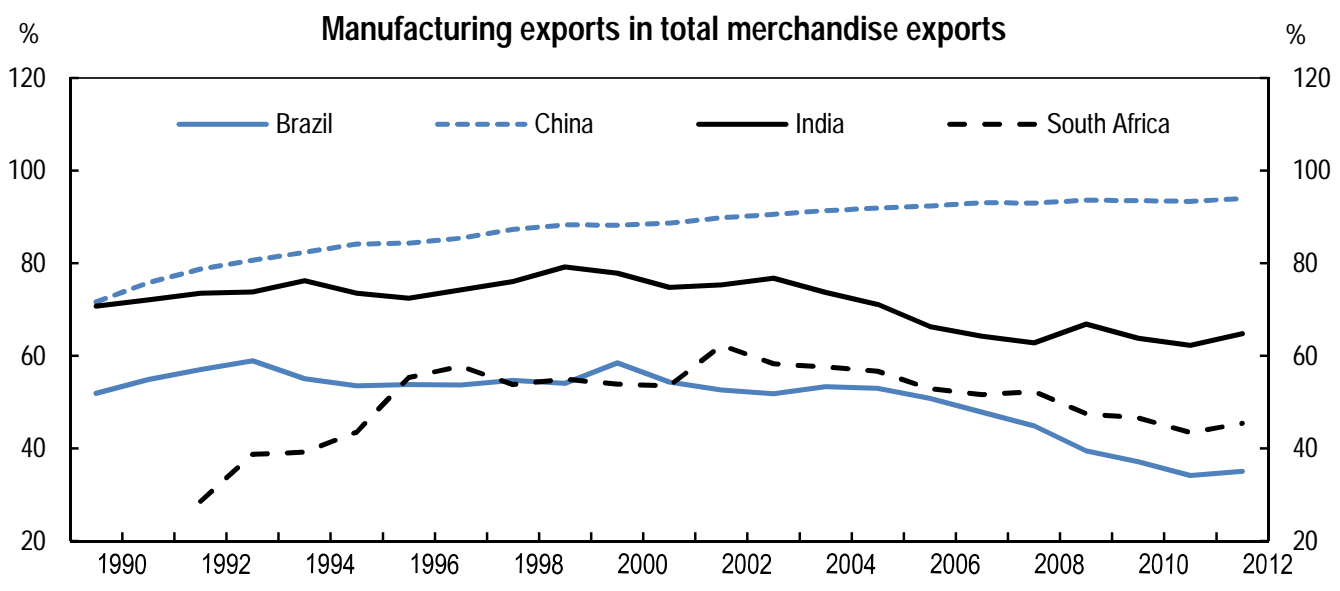

Source: World Bank, World Development Indicators database.

The OECD data on trade in value-added show that India has fewer manufacturing sub-sectors with a revealed comparative advantage (RCA) than other emerging economies (Table 1). This confirms India's lack of specialisation in this sector. In addition, when a manufacturing sub-sector displays an RCA, it tends to be relatively small, as for example in the case of the production of textiles, textile products, leather and footwear. The main exception is the "manufacturing not elsewhere classified (nec)", which consists mainly of jewellery, where India has a significant RCA. On the other hand, India displays stronger and more RCAs in several service sectors.

The cost of labour in India has remained relatively low. Focusing on the organised manufacturing sector, the US Labour Bureau data show that average hourly compensation costs in India in 2009 were about $25 \%$ lower than in China. Nevertheless, Indian manufacturing is surprisingly capital intensive compared to China and Indonesia (Figure 7, panel A). In 11 out of 14 manufacturing sub-sectors, India has the highest capital-labour ratio. India has also specialised in more skill-intensive production compared to its peers (Figure 7, panel B). Hasan et al. (2012) show that India's organised manufacturing has higher capital-intensities than countries at the same level of development and with similar factor endowments. Kochhar et al. (2006) argue that India has emphasized skill-intensive rather than labour-intensive manufacturing, and in terms of productivity skill-intensive sectors stand out. Kapoor (2014) further argues that recent economic growth has benefitted industries which rely more on capital and skilled workers as opposed to low skilled workers.

India should better channel employment from low productivity agriculture to higher productivity manufacturing and services, which would raise wages and living standards for a larger share of the population. Furthermore, India should aim for more formal jobs in the organised manufacturing sector, as these tend to be the most secure and of highest productivity. Indeed, household surveys show that male urban manufacturing workers with regular jobs on average get a salary 2.5 times the level of casual contract workers in the same sector (NSSO, 2011-12). Informality is typically associated with lower productivity and many workers remain outside the reach of labour market regulations and social protection schemes, resulting in higher inequality (OECD, 2011b). 
ECO/WKP(2015)1

Table 1. India has a comparative advantage only in a small number of manufacturing sectors

\begin{tabular}{|c|c|c|c|c|c|c|c|}
\hline & India & Brazil & China & Indonesia & South Africa & Thailand & Vietnam \\
\hline \multicolumn{8}{|l|}{ Industry } \\
\hline Mining and quarrying & 0.50 & 0.85 & 0.35 & 2.57 & 2.70 & 0.18 & 2.07 \\
\hline Food products, beverages and tobacco & 0.35 & 2.51 & 0.94 & 3.03 & 0.82 & 3.10 & 3.40 \\
\hline $\begin{array}{l}\text { Textiles, textile products, leather and } \\
\text { footwear }\end{array}$ & 1.39 & 0.63 & 3.77 & 1.93 & 0.25 & 3.04 & 3.19 \\
\hline $\begin{array}{l}\text { Wood, paper, paper products, printing } \\
\text { and publishing }\end{array}$ & 0.39 & 1.27 & 1.07 & 1.35 & 0.84 & 0.71 & 0.75 \\
\hline $\begin{array}{l}\text { Chemicals and non-metallic mineral } \\
\text { products }\end{array}$ & 0.71 & 0.86 & 1.13 & 1.39 & 0.73 & 1.31 & 0.35 \\
\hline $\begin{array}{l}\text { Basic metals and fabricated metal } \\
\text { products }\end{array}$ & 0.72 & 1.61 & 1.45 & 0.36 & 1.34 & 0.75 & 0.16 \\
\hline Machinery and equipment, nec ${ }^{1}$ & 0.37 & 0.50 & 1.08 & 0.44 & 0.00 & 0.31 & 0.16 \\
\hline Electrical and optical equipment & 0.63 & 0.32 & 2.08 & 0.64 & 0.12 & 2.40 & 0.18 \\
\hline Transport equipment & 0.42 & 0.93 & 0.56 & 0.61 & 0.69 & 0.77 & 0.22 \\
\hline Manufacturing nec; recycling & 3.33 & 0.26 & 2.53 & 0.78 & 1.03 & 2.25 & 0.58 \\
\hline Utilities & 0.78 & 1.02 & 1.28 & 0.31 & 0.95 & 1.16 & 0.55 \\
\hline Construction & 1.43 & 0.81 & 0.15 & 0.91 & 0.83 & 0.07 & .. \\
\hline \multicolumn{8}{|l|}{ Memorandum items: } \\
\hline $\begin{array}{l}\text { Number of manufacturing sectors in which } \\
\text { the country has comparative advantages: }\end{array}$ & 2 & 3 & 7 & 4 & 2 & 5 & 2 \\
\hline $\begin{array}{l}\text { Number of service sectors in which the } \\
\text { country has comparative advantages: }\end{array}$ & 4 & 2 & 0 & 0 & 3 & 1 & 1 \\
\hline
\end{tabular}

1. Nec stands for not elsewhere classified.

Note: The revealed comparative advantage (RCA) is an index measuring a country's specialisation in a given industry by comparing the share it represents in the country's exports to the world share of the industry in world exports. There is comparative advantage when the RCA is greater than 1. Here, the RCA is calculated in value added terms, indicating which sectors contribute more to the domestic value added embodied in the gross exports of the country.

Source: OECD-WTO Trade in Value Added (TiVA) - May 2013. 
Figure 7. Manufacturing is highly capital and skill intensive

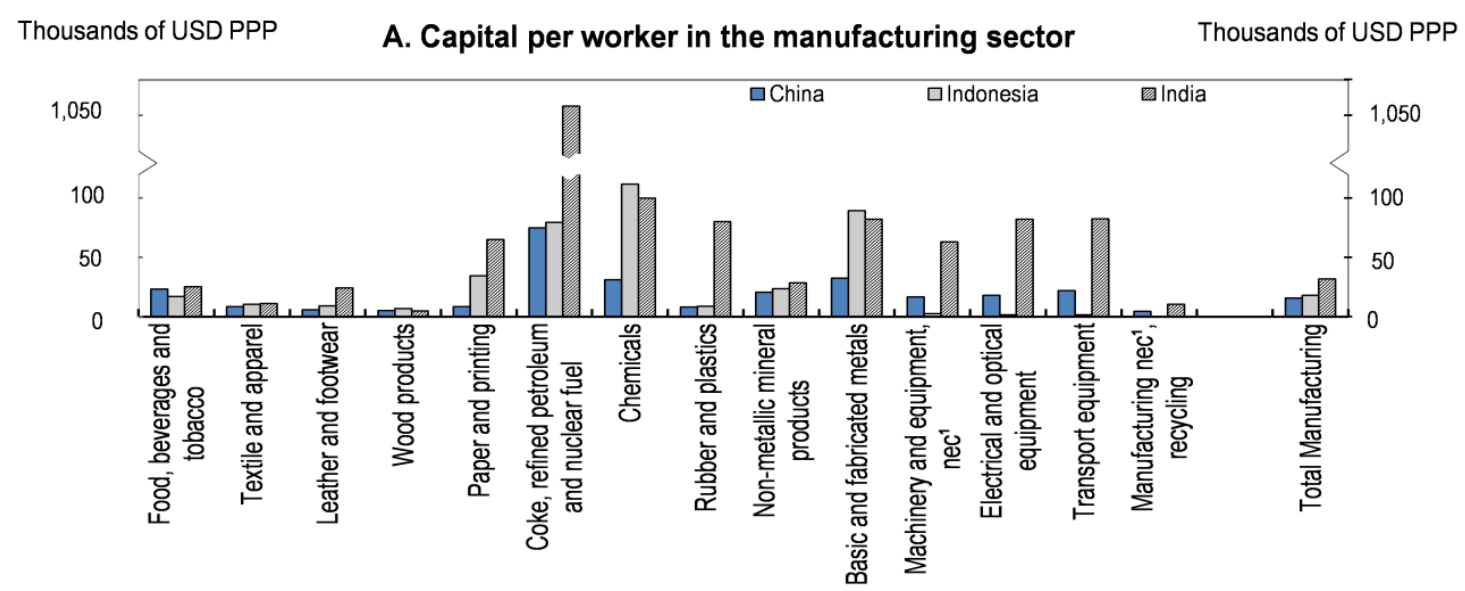

B. Contribution of high skilled workers ${ }^{2}$ to value added by sector

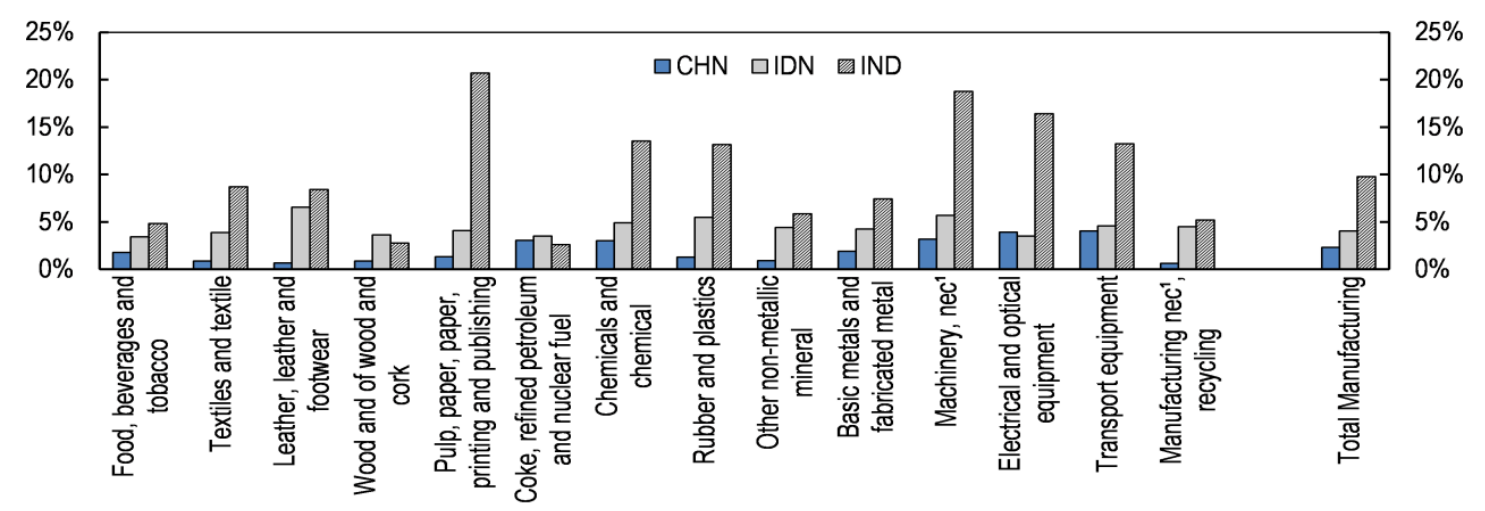

Note: Data refer to the average values over the period 2005-09.

1. nec stands for "not elsewhere classified".

2. Following the 1997 International Standard Classification of Education (ISCED), high skilled workers are defined as workers with first or second stage of tertiary education.

Source: WIOD database, February 2012 release.

\section{Lifting barriers to manufacturing}

Various measures to boost manufacturing have been introduced since the early 2010s. The 2011 National Manufacturing Policy (NMP) is meant to increase the share of manufacturing to $25 \%$ of GDP and to create 100 million additional jobs by 2022. The 2014 Make in India initiative goes in the same direction (Box 2). The Delhi-Mumbai Industrial Corridor (DMIC) project, in cooperation with Japan, aims to develop an industrial zone spanning six states by expanding infrastructure and industry. Relatively restrictive FDI policy has gradually been relaxed and a not-for-profit single window facilitator for prospective overseas investors, "Invest India", has been set up. The government has also stated that promoting labour-intensive manufacturing is one of its top priorities.

While these plans are welcome, India could do more to address fundamental problems with the overall business environment. Currently, policies rely heavily on the economic zones (see Box 3) that provide exemptions from many existing policies such as labour regulations, taxation or business creation. When zones are set up to boost employment and growth, they are successful mostly if they can have a wider impact on the economy and do not operate as enclaves with few linkages to the domestic economy. Still, such zones may act as catalyst for reforms, facilitating progress towards more country-wide reforms. 
International experience, however, suggests that they work best in countries with good infrastructure and financial markets, where forward and backward linkages can be successfully developed to domestic economic activity (OECD, 2014; Farole, 2011).

\section{Box 2. National Manufacturing Policy (NMP) and the "Make in India" initiative}

\section{National Manufacturing Policy}

The NMP has six objectives: i) Increase manufacturing sector growth to $12-14 \%$ over the medium term, to contribute at least $25 \%$ of the National GDP by 2022; ii) Promote job creation in manufacturing with a target of 100 million additional jobs by 2022; iii) Create appropriate skills among the rural migrants and urban poor to make growth inclusive; iv) Increase domestic value addition and technological depth in manufacturing; v) Enhance global competitiveness of Indian manufacturing; vi) Ensure sustainability of growth, particularly with regard to the environment.

The NMP provides special focus to industries that are employment intensive, those producing capital goods, those having strategic significance and where India enjoys a competitive advantage (automobile, pharmaceuticals and medical equipment), small and medium enterprises, and public sector enterprises - the so-called Special Focus Sectors.

The NMP stipulates creation of national investment and manufacturing zones (NIMZs), which will be newly set up cities to ensure agglomeration economies, superior infrastructure, lower red tape, flexible labour market regulation and skilled labour.

The broad policy instruments are: i) Rationalisation and simplification of business regulations; ii) Simple and expeditious exit mechanism to close sick units while protecting labour interests; iii) Financial and institutional mechanisms for technology development, including green technologies; iv) Industrial training and skill up-gradation measures; v) Incentives for SMEs; vi) Special Focus Sectors; vii) Leveraging infrastructure deficit and government procurement - including defence; viii) Clustering and aggregation through National Investment and Manufacturing Zones (NIMZs); ix) Trade Policy that does not adversely impact domestic manufacturing.

While the NMP has clear outcome targets, progress up to 2014 has been limited. The implementation of policy reforms to reach these targets has remained a challenge.

\section{"Make in India"}

On September 2014, Prime Minister Modi announced the "Make in India" campaign to promote the manufacturing sector and spur job creation. The Prime Minister invites foreign companies to invest in India and promises that his government will provide effective and easy governance to help India become a global manufacturing hub. The key objective is to simplify regulations and reporting requirements and ensure more stable policies, including tax policies.

Major highlights of Make in India:

- Easing policies and laws: A comprehensive approach is envisaged, including amending labour laws, developing skills, easing FDI policies and up-scaling infrastructure.

- An Invest India team and a dedicated portal for business queries: An investor facilitation team set up by the government will act as the first reference point for guiding foreign investors on all aspects of regulatory and policy issues and to assist them in obtaining regulatory clearances. The information and facts that potential investors need for each sector have been compiled in brochures. A dedicated team has been created to answer queries from companies through a newly created web portal, pledging to answer queries within 72 hours.

- Consolidated services and faster security clearances: All central government services are being integrated into an e-Biz single window online portal. The Ministry of Home Affairs will give all security clearances to investment proposals within 3 months and government departments are asked to streamline approval processes.

- 25 sectors where India can be a world leader have been identified: Make in India will focus on creating jobs and enhance skills in these sectors, which include capital goods and engineering, defence equipment, pharmaceuticals, food processing, auto and auto components, textiles and electronics.

Make in India builds on the NMP and is in most respects consistent with it, although it more openly extends a hand to foreign investors. 


\section{Box 3. Special Economic Zones (SEZs) and National Investment and Manufacturing Zones (NIMZs)}

\section{Special Economic Zones (SEZs)}

The government created Special Economic Zones (SEZs) more than 50 years ago with the objective of generating additional economic activity, exports, investment and employment. Since 2006, the policy relies on private developers to create the zone and provide the infrastructure. Imports into the SEZ are tax and tariff free, but sales to the domestic market are regarded as imports into India. In the SEZ, a single window clearance for development is in place and there are simplified administrative procedures and exemptions from many restrictive policies, including labour laws, allowing to contract labour more freely (OECD, 2007, 2011a).

Significant tax concessions have also been granted. Total corporate tax exemption for five years, $50 \%$ for a further five years and a further exemption for re-invested earnings derived from exports, with developers allowed a ten-year window of tax exemption. Zone developers are exempt from the minimum alternate corporate tax and the dividend distribution tax. However, from FY 2011 the government imposed a Minimum Alternate Tax (MAT) and it also introduced a Dividend Distribution Tax. Furthermore, for SEZs established from 2014 onwards tax holidays are replaced by complete first-year depreciation, providing a further bias towards capital-intensive projects.

SEZs provide an important platform for development in India. Since 2006, formal approvals have been granted for 579 SEZs, of which 160 are exporting goods and services, and total employment in SEZs is estimated to approach 1 million. From 2005-6 to 2010-11, exports from these areas have risen 16-fold in current rupees and in 2010-11 they accounted for about one-fifth of total exports of goods and services (OECD, 2011a, CEIC and Ministry of Finance, 2013a).

However, a common grievance is that the SEZs failed to achieve the objective of encouraging manufacturing exports and instead became attractive centres for information technology firms to benefit from tax incentives. Indeed, some interest for investing in the SEZs was lost when the government imposed a minimum alternate tax in 2012. In addition, the Indian Council for Research on International Economic Relations (ICRIER) reports that giving additional export incentives to exporters outside SEZs in 2009 acted as a disincentive to invest in SEZs. Furthermore, by signing free-trade agreements with countries where duties on many products have been eliminated or reduced the advantages accruing to SEZs have been reduced further (Mishra, 2013).

\section{National Investment and Manufacturing Zones (NIMZs)}

National Investment and Manufacturing Zones (NIMZs) are a core element of the National Manufacturing Policy (NMP). They were announced in 2011. In contrast to the SEZ framework, NMIZs would not involve tax concessions or have export requirements, but would rather focus on providing supportive policy environment for business (OECD, 2011a). These zones will be greenfield industrial townships with a minimum area of 5,000 hectares. Each zone will be managed by a special purpose vehicle, headed by a government official. The NMIZs will focus on providing a more supportive policy environment for business than presently available. The NIMZs would be a combination of production units, public utilities, logistics solutions, environmental protection mechanisms, residential areas and administrative services. They would have a processing area, where the manufacturing facilities will be located, and a non- processing area, to include residential, commercial and other social and institutional infrastructure. The processing area may include one or more Special Economic Zones, Industrial Parks \& Warehousing Zones, and Export Oriented Units. So far seventeen NIMZs have been given inprinciple approval by the government, of which eight are along the DMIC.

Some of the key elements of the NMIZs include: more flexible labour practices; easier exit strategy for ailing companies; special incentives for green technologies; simplified clearance and approval; single window clearance for central and state level approvals; and skill development programs for employees (OECD, 2011a, Ministry of Finance, 2014 and 2013b, Planning Commission, 2011). 
Manufacturing growth is constrained by a complex business environment. India ranks 134th out of 189 countries in the World Bank Doing Business 2014 data. However, variations between regions are large. The World Bank (2009) showed that if one creates a hypothetical city with best practices found across India (e.g. lowering number of procedures to start a business to Patna levels, days to start a business to Mumbai levels, procedures around construction permits to Ahmedabad levels, days to enforce a contract to Guwahati levels, and recovery rate for closing a business to Hyderabad levels), it would rank a much improved 67 out of the 181 economies measured by Doing Business 2009. Apart from regulations governing doing business, manufacturing is affected by stringent labour regulations, infrastructure bottlenecks, and the tax system. Policies are needed to address all these issues.

\section{Reforming labour regulations to support enterprise growth}

\section{Complex and strict labour regulations imply large compliance costs and discourage formal job creation}

The multitude of labour laws, not all of them being consistent, creates confusion and uncertainty, and raise labour costs (Bhagwati and Panagariya, 2013; Kumar, 2012; 2007 OECD Survey; Papola, 2013). Labour is a "concurrent" (joint) responsibility, as both central and state governments can enact laws. As an example, the minimum wage system is one of the most complicated in the world. State governments fix different rates payable to different employees in a limited number of sectors and occupations, resulting in 1171 different minimum wage rates (Belser, 2013). Adding to the complexity, some laws enacted by one government level are enforced by another, or by both. Key labour laws may not use the same definitions, e.g. for employees/workers, requiring firms to maintain various registers. In addition, most labour regulations have been designed several decades and some may have lost relevance - e.g. the 1948 Factories Act regulates hygienic conditions in an outdated manner (Kumar, 2012). Compliance costs are thus high. Since some companies may not be aware of their precise obligations, non-compliance in some areas becomes inevitable, opening the door to corruption by labour department inspectors (Bhagwati and Panagariya, 2013; Papola, 2013).

Stringent labour laws are often blamed for the poor performance of labour intensive manufacturing industries and sluggish job creation, despite relatively low wages (Ministry of Finance, 2013d), Economic Survey 2012-13; Dougherty et al., 2013). Labour regulations are more stringent for large companies, with varying thresholds above which regulations become applicable (Table 2). Employment protection legislation (EPL) for regular employment is particularly high in industrial establishments with more than 100 workers (Figure 8), largely because industrial firms are required to obtain prior government permission to dismiss one or more workers. In addition, the frequency of reinstatement orders in the case of unfair dismissal is high while delays in resolving labour disputes may be long (Bhattacharjea, 2009), adding to uncertainty and indirect costs of labour. 
Table 2 Many labour regulations become binding as companies grow

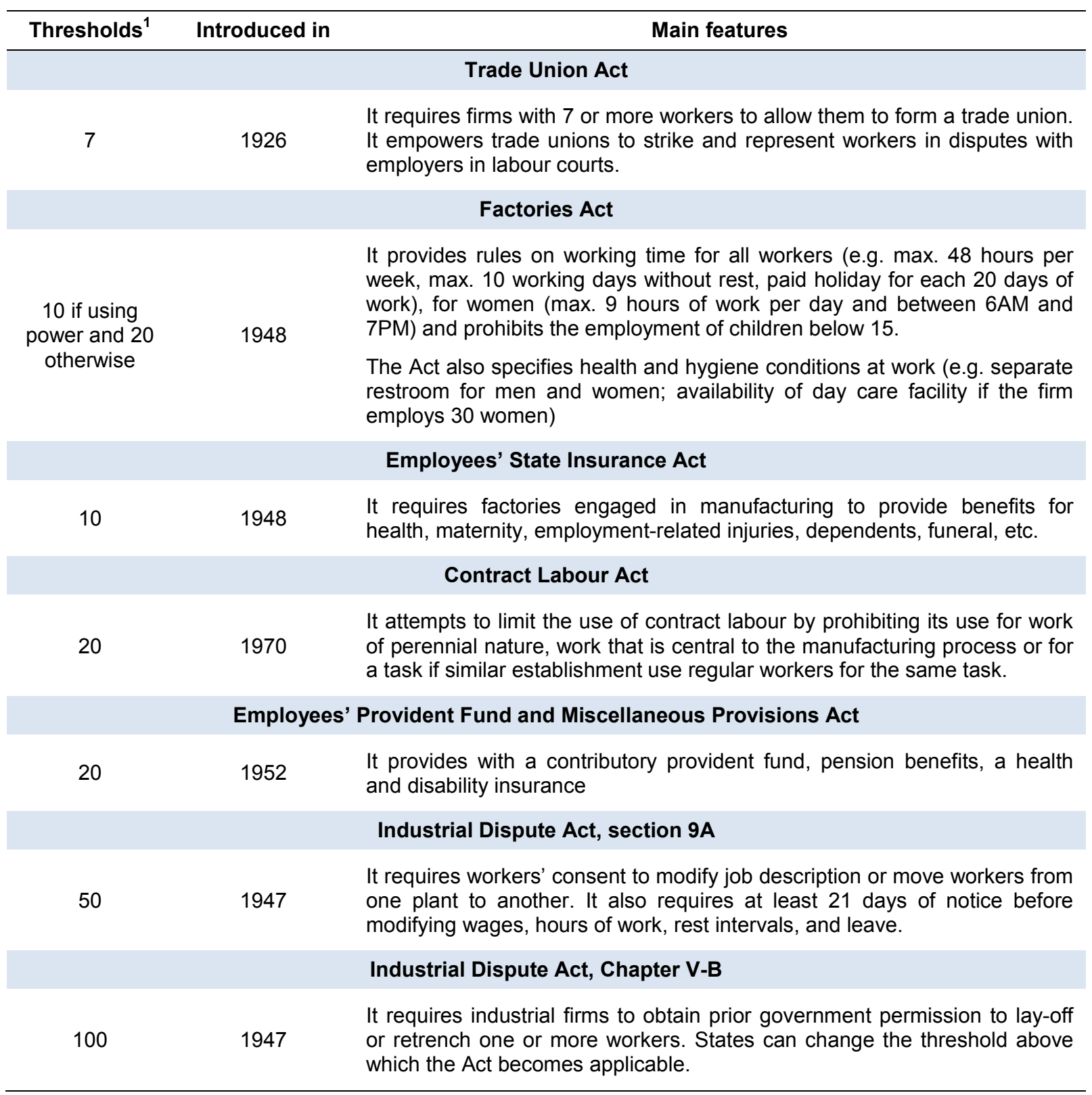

1. Number of employees when the law becomes binding.

Source: OECD Secretariat. 
Figure 8. Employment protection legislation is highly restrictive ${ }^{1}$

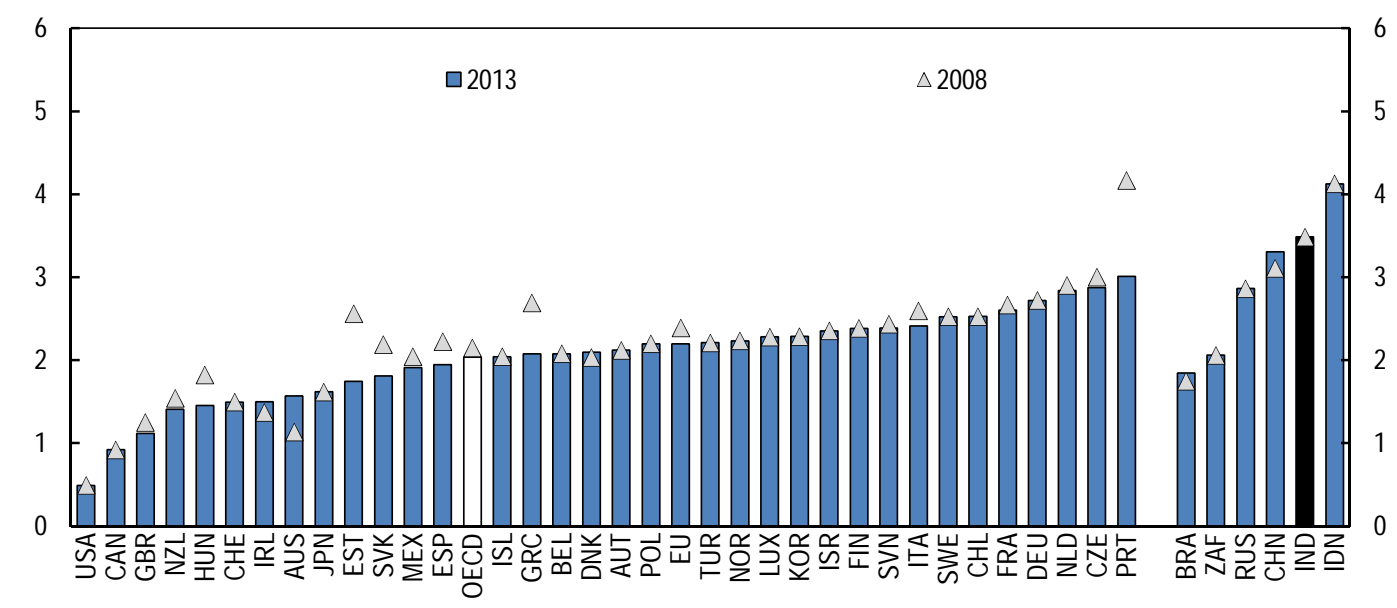

1. The OECD indicator of employment protection legislation (EPL) for regular employment measures the procedures and costs involved in dismissing individual regular employees. The indicator runs from 0 to 6 , representing the least to most restrictive. The last available data refer to 2012 for BRIICS countries.

Source: OECD Employment Protection Database, 2013 update.

Although labour taxes are relatively low in India, they increase steeply with firm size. Firms with less than 20 employees are not required to comply with the Employees' Provident Fund Act and do not have to pay pension, health and disability contributions. Firms with more than 20 employees do have to contribute and, although the tax wedge remains relatively modest even for them (Figure 9), the steep increase acts as a disincentive to grow.

Figure 9. The average tax wedge on labour is relatively low, especially in small firms

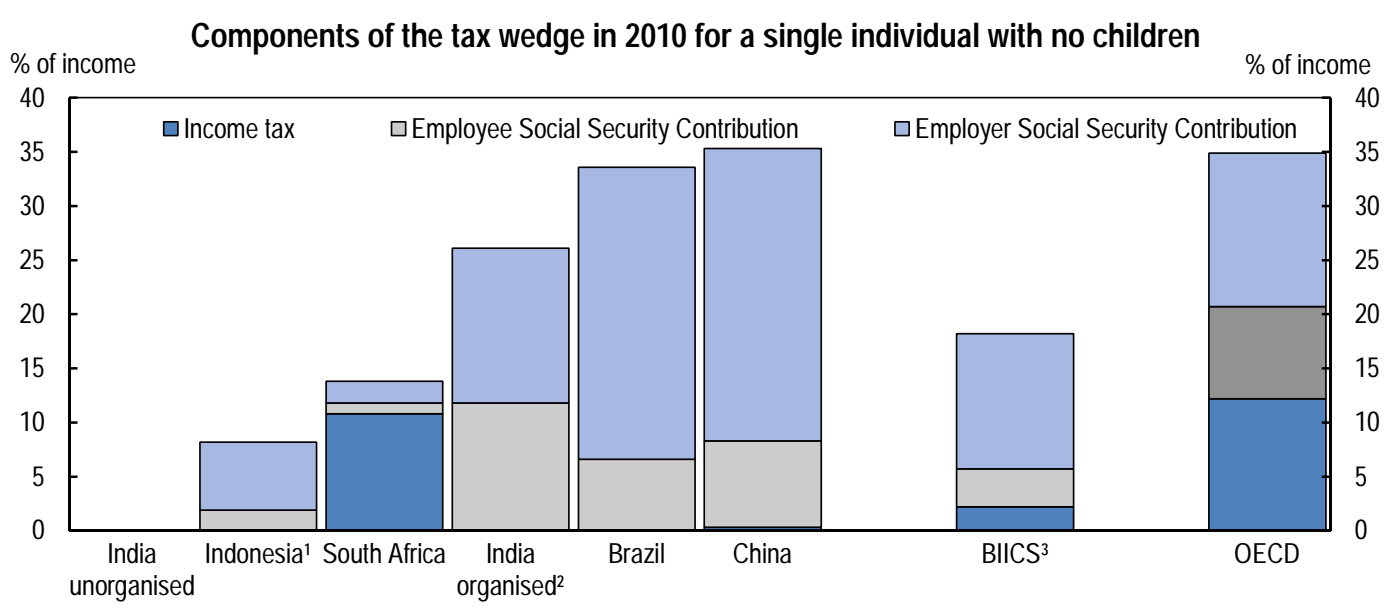

Note: the tax wedge is given by the average percentage of income paid in income taxes and social security contributions by a single individual with no children, earning the average wage.

1. Results for Indonesia are for 2009.

2. Results for the case where the employee works in a firm with more than 20 employees. In India, firms with more than 20 employees have to comply with the Employees' Provident Fund and Miscellaneous Provisions Act and thus pay social security contributions (see Table .2).

3. The BIICS average is calculated using the standard "India unorganised" results, not "India organised".

Source: Gandullia et al. (2012).

Firms have substituted labour for capital, at least in part, to escape labour regulations. As noted above, capital investment has been the main factor behind the growth in value added in most manufacturing 
industries over the past decades. The capital intensity of Indian firms is also higher than in similar countries (see above and Kochhar et al., 2006). Bhagwati and Panagariya (2013) further note that the fastest growing industries over the past two decades have been either capital-intensive or skilled-labour intensive (vehicles, petroleum refining, engineering goods, telecommunications, pharmaceuticals, finance and software).

Labour regulations have also created an incentive for firms to stay small and to rely on "informal" labour. By staying small, manufacturing firms do not have to comply with key labour regulations as these become applicable above various employment thresholds. Hasan and Jandoc (2012) find that firms in labour-intensive industries tend to be larger in states with flexible labour regulations; this difference is higher among firms created after 1982 when the EPL was tightened. By staying small, however, firms cannot exploit economies of scale, lowering productivity.

Another strategy for firms to escape stringent labour regulation, in particular EPL, has been to rely on "contract labour", i.e. workers hired on a temporary basis or through a contractor. The Labour Bureau data reveal that contract workers accounted for more than a third of the workers in the organised manufacturing sector in 2010 . The share is very high compared to the OECD average, where temporary employment stood at $12 \%$ of total employment. Hasan and Jandoc (2012) further note that the increase in the use of contract labour has been steeper in labour-intensive manufacturing enterprises with 50 to 99 workers, suggesting that the 100 workers threshold of the Industrial Dispute Act (IDA) is binding. The share of employees not covered by social insurance is much higher. According to Mehrotra et al. (2014), and on the basis of NSSO data, almost $70 \%$ of employment in the organised manufacturing sector was informal (i.e. with no social security benefits) in 2011-12.Labour reforms have been initiated but bolder steps are needed

Initiatives have been taken at the central and state government levels to reduce the detrimental impacts of labour regulations. The central government issued guidelines in the early 1980s to reduce the frequency of inspection by labour officials, with a view to preventing unnecessary harassment of, and cost to, employers (Papola, 2013). It has also allowed states to exempt enterprises in various economic zones (e.g. NMIZs, SEZs or Export Processing Zones) from several labour laws. In 2014, the incoming government introduced Bills for amendment in the Factories Act and Apprenticeship Act. It also introduced a single window - a website - to help businesses meet compliance requirements for various labour laws. The new system would also make labour inspections more transparent by using a random computerised method and the redressal of grievances more effective. In November 2014, the threshold below which small establishments are exempted from furnishing returns and maintaining registers has been increased to between 10 and 40 people (from 10 to 19 earlier).

At the state level, there is considerable variation in the implementation of the provision of the Industrial Dispute Act (IDA) which requires government permission for layoff and retrenchment of workers and closures of industrial establishments (Besley and Burgess, 2004; Bhattacharjea, 2009; Dougherty et al., 2013, Papola, 2013). Some states (e.g. Maharashtra and Gujarat) do not apply the EPL as contained in the Industrial Dispute Act (IDA) and several states have exempted selected industries and sectors from its application. In contrast, others (e.g. West Bengal) have made the IDA more restrictive. Significant changes in the rules and practices under the Contract Labour Act (CLA) have been made so as to make it easier for firms to use temporary employment. In particular, several states have exempted a number of industries from the application of the prohibitive clauses of the CLA. Most recently, Rajasthan made amendments to key labour laws. In particular, the Contract Labour Act will now apply to companies with more than 50 workers, instead of 20, and the Factories Act will apply to premises with more than 20 workers with power and 40 without power, up from the 10 and 20, respectively. Various empirical surveys (most recently Kapoor (2014)) suggest that states with inflexible labour regulations have witnessed slower growth in manufacturing output and employment than states with more flexible labour regulations. 
Bolder reforms would further promote quality employment and reduce income inequality. Work on OECD countries suggests that reducing labour market dualism by narrowing the gap between the protection of permanent and temporary jobs lowers income inequality by reducing both wage dispersion and unemployment (Koske et al., 2011). In India, the large unorganised and informal sectors, which leave many workers with low income and virtually no social protection, contribute to labour market segmentation. Reforming labour regulations should aim at providing a minimum floor of pay and social and labour protection conditions for all workers irrespective of the status, size and activity of the firm. This would require introducing a comprehensive labour law which would consolidate and simplify existing regulations. In turn, this would reduce uncertainty surrounding regulations as well as compliance costs for manufacturing companies. Barriers to formal employment should also be reduced, in particular by abolishing the most restrictive provisions of the Industrial Dispute Act that require prior government permission for employment termination and exit decisions. At the same time, the new law should consider providing better training and assistance in job search.

Finally, the lack of consistent time series and timely data makes it difficult to assess labour market outcomes and to design appropriate policies. Households surveys (NSSO) are extremely detailed but are carried out only once every five years and results are published with a considerable lag. The Labour Bureau is now publishing annual Employment Surveys but these do not allow to correctly identify underemployment and seasonal employment, which are fairly common, and their sampling criteria do not match those of the NSSO. The large size of the informal economy is a difficulty but has not prevented other countries with a large informal sector and populations settled in remote areas to publish frequent, reliable and timely data on the labour market - Brazil and Colombia are examples. Quarterly employment surveys conducted by the Labour Bureau since 2008 cover only a few manufacturing and service sectors and the government is considering widening its scope. Improving the consistency and timeliness of labour market data should indeed be a priority.

\section{Improving education and training}

\section{The general education level is low}

Employers complain of major skills gaps, and fewer than a quarter of graduates are estimated to be employable in manufacturing (Planning Commission, 2011). Workers trained in the vocational education and training (VET) system often require significant on-the-job training (World Bank, 2009). On the other hand, India has a small number of elite higher education institutions that have produced highly-skilled graduates for the successful service sector. This points to the benefits of greater investment in quality education, which is essential to enhance skills, and would also reduce inequality and social exclusion (Kumar and Liu, 2008).

Improving access to education and raising literacy are crucial. The 2009 Right of Children to Free and Compulsory Education Act (RTE) has substantially improved access to primary education approaching a near-universal enrolment. The RTE Act aims at education for all children between 6 to 14 years by providing for the establishment of neighbourhood schools and school infrastructure, and an adequate number of trained teachers $(65 \%$ of the funds provided by the central government). However, despite progress the literacy level for the population aged 7 years and above remains low at $73 \%$ (2011 Census India) (Figure 10). Furthermore, enrolment rates at secondary and tertiary levels are also low. The secondary school is the most neglected part of the education sector, despite being critical in moving educated youth into higher education or onto the labour market (IDFC Foundation, 2013). With the 2009 Secondary Education for All Action Plan the government aims at providing universal access to secondary education by 2017. 
A key issue is the quality of education. Two states participated in the 2009 pilot survey round of the OECD's Programme for International Student Assessment (PISA), which assesses the performance of 15year-old students in reading, mathematics and science. The top 5\% of students in India performed close to the OECD average, illustrating what is achievable in India. However, the results showed that the average performance of 15-year-old students was far below the OECD average and well behind other emerging economies (Figure 11). Moreover, according to the Annual Status of Education Report (ASER) 2012 (Ministry of Finance, 2013c), basic reading and arithmetic level and attendance of school children across rural India have even declined in recent years. The quality is also low in higher education; the National Accreditation and Assessment Council reports that $90 \%$ of universities and $70 \%$ of colleges are of mediocre or poor quality (IDFC Foundation, 2013).

As a step to raising quality, monitoring learning outcomes and tracking implementation and progress of reforms is essential. Better motivated and higher-quality teachers are needed at all levels of education, and teacher absence, which has been a problem, must be reduced. Employment arrangements for public school teachers need to be reformed by strengthening dismissal provisions for teachers who are repeatedly absent or not performing satisfactorily. At the same time, teachers should be given better training and the framework for teacher development should be strengthened (OECD, 2011a). The education sector operates in a restrictive regulatory environment. Although there has been a notable rise in private participation in the education sector, private institutions are restricted to function on a non-profit basis, possibly preventing serious players from stepping in (IDFC Foundation, 2013; OECD, 2011a). 
Figure 10. Literacy and enrolment rates are low
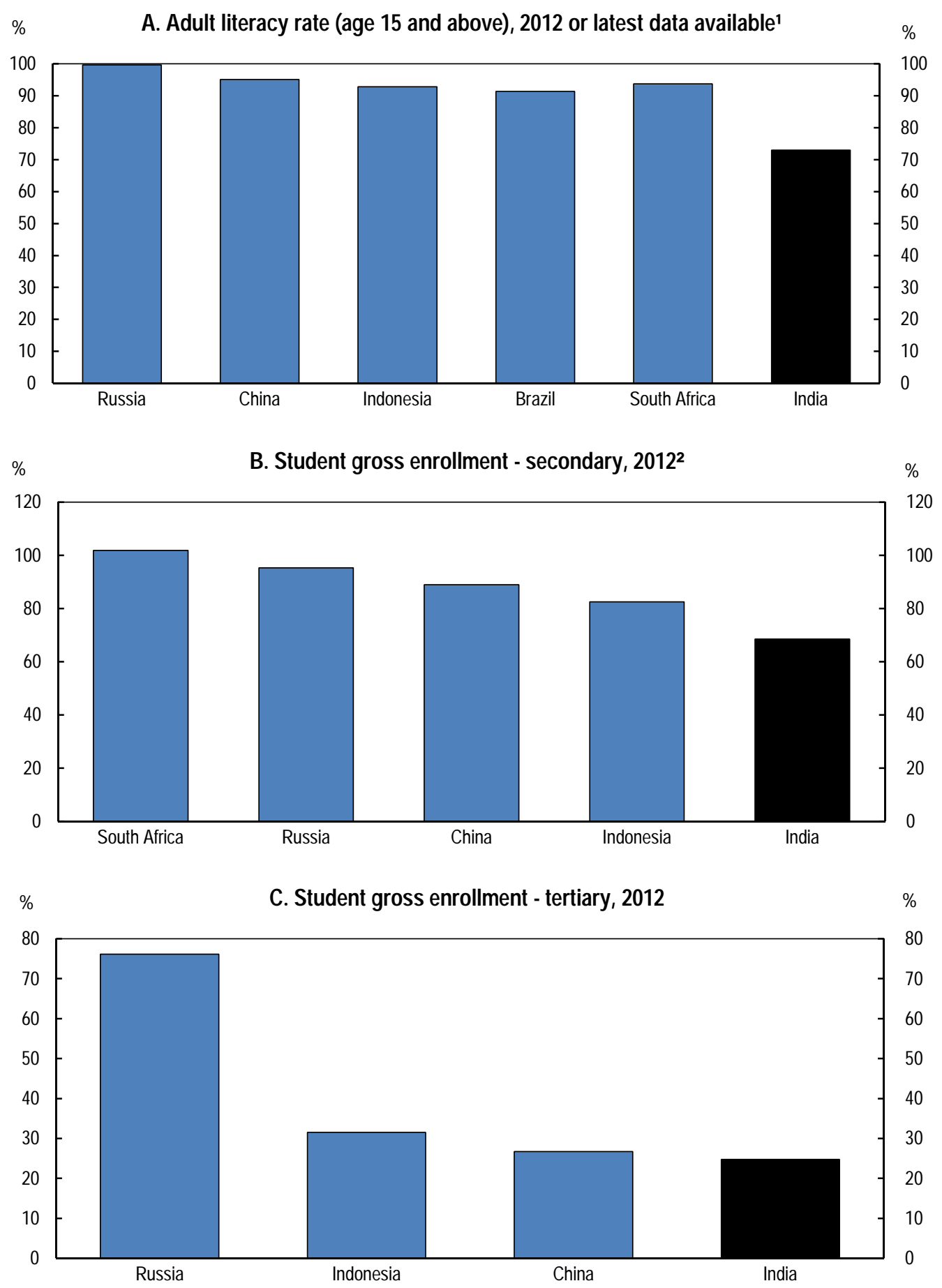

1. For India the data concern population aged 7 and above, thus the figure slightly overestimates the literacy rate in comparison to other countries. For India and Indonesia, data are for 2011, for China and Russian Federation for 2010, and for Brazil and South Africa for 2012.

2. Data for India are for 2011.

Source: World Bank WDI databank and Census 2011 for India. 
Figure 11. Learning outcomes are low

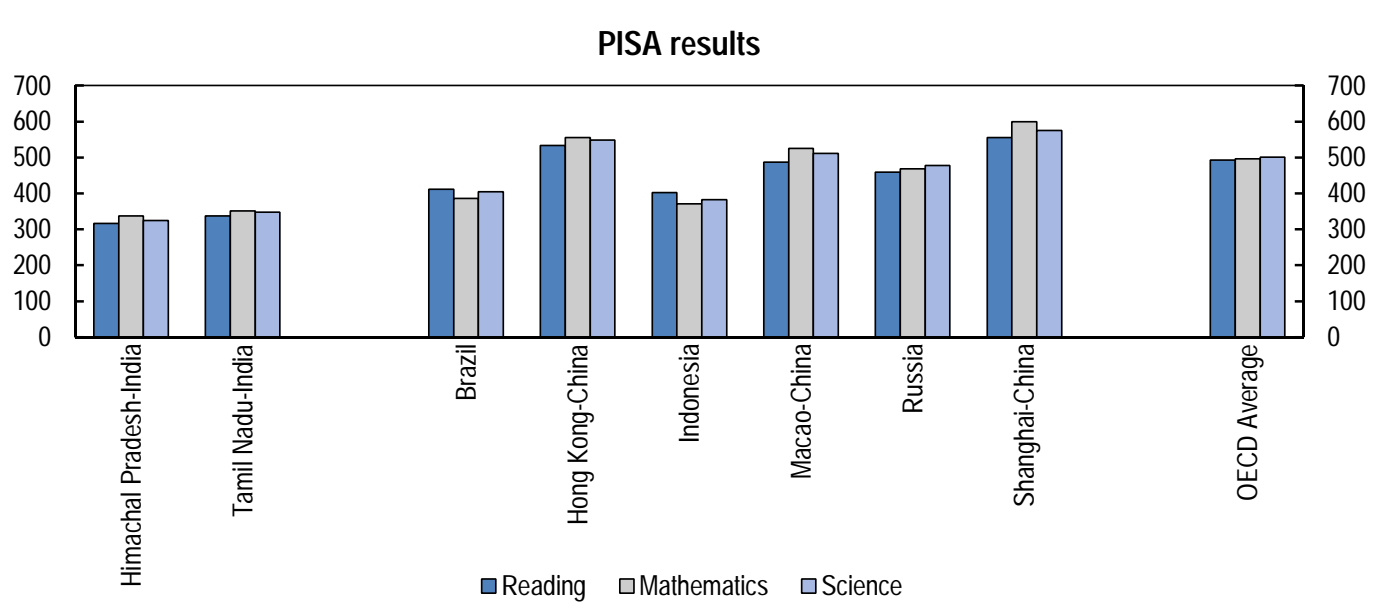

Note: The Programme for International Student Assessment (PISA) is a triennial international survey which aims to evaluate education systems worldwide by testing the skills and knowledge of 15 -year-old students.

Source: PISA 2009 Plus Results.

\section{Strengthening vocational education}

Only $10 \%$ of the labour force aged $15-59$ is vocationally trained. In manufacturing, only $10 \%$ of those trained received formal vocational education, while in services this share is $40 \%$ (Planning Commission, 2013). The rest receive non-formal on the job training. The skill deficit reflects the large size of the unorganised sector, which tends to have low-paid, low-productivity jobs with limited access to training. It is therefore important to target formal training also for the workers in the unorganised sector.

The National Policy on Skill Development, adopted in 2009, sets out ambitious objectives to improve the quality and relevance of skills training - 500 million people are to be trained by 2022 . The National Skill Development Corporation (NSDC) facilitates private-public partnerships for skill development by providing funding to enterprises and organisations that offer training. The NSDC has the objective to deliver training to about 150 million people by 2022, mainly in the unorganised sector. However, the industry skill requirements could be better taken into account and on-the-job training should form an important part of any formal training (OECD, 2010). For this, it is essential that the authorities and the private sector work in partnership, especially in developing the curriculum. Furthermore, the curriculum should be reviewed every two to three years, with inputs from academic and industry experts (IDFC Foundation, 2013). The government has recently announced initiatives to revamp curricula by bringing industry on board, also through sector mentor councils, which is a positive step. The government should also develop schemes to finance training, as many job-seekers are unable to pay for it, possibly through voucher schemes and loan guarantees.

\section{Addressing infrastructure bottlenecks}

In the last 20 years, India has invested substantially in infrastructure, although not as much as China (Figure 12). In many areas, investment targets have not been met, leaving infrastructure in poor condition. Firms in India face frequent power outages and transport infrastructure is below par. This has an especially harmful effect on manufacturing, which is a sector highly reliant on well-functioning infrastructure. Senior managers of top manufacturing firms identify the state of infrastructure as one of the biggest challenges for manufacturing growth and they cite that improving infrastructure should be the top priority for the government (CII-BCG, 2012; FICCI, 2011). Using difference-in-difference estimates on a sample of firms from the Annual Survey of Industries, Gupta et al. (2008) find evidence that the industries more dependent 
on infrastructure (measured by the firms' share of expenses on distribution, i.e. storage and transportation, and power and fuel in gross value-added) exhibited slower growth since the early 1990s compared to less infrastructure-dependent industries.

Figure 12. Investment in infrastructure across countries

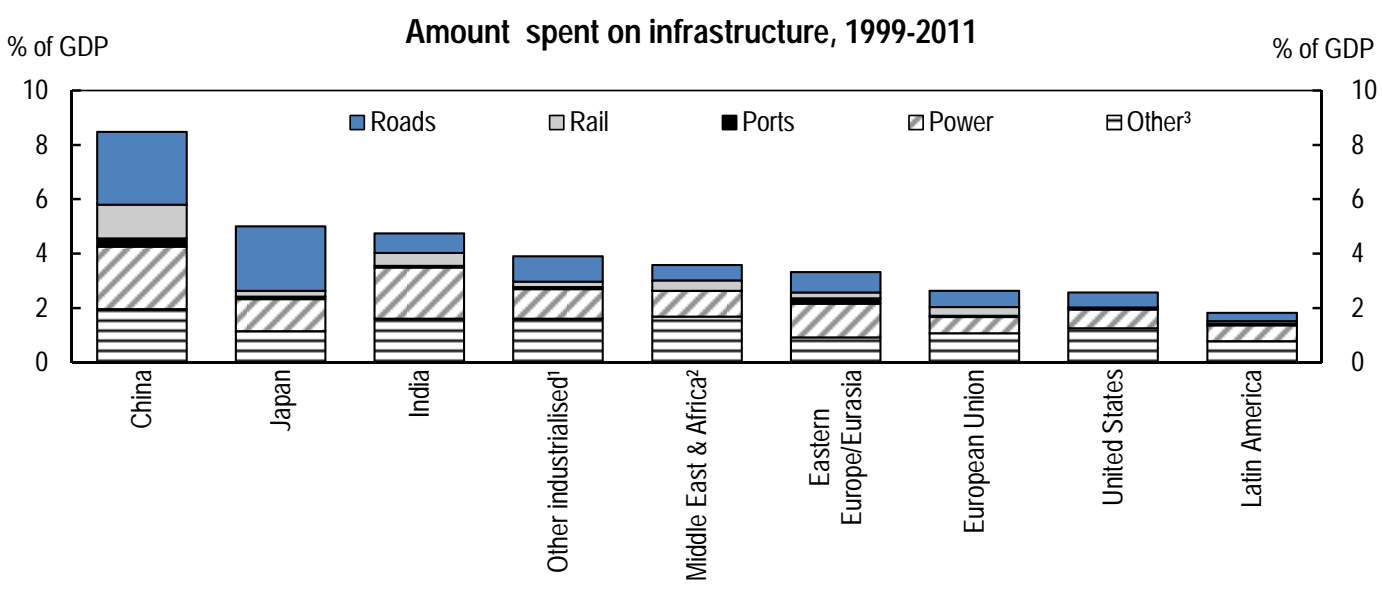

1. Other industrialised: Australia, Canada, Croatia, Iceland, Lichtenstein, New Zealand, Norway, Singapore, South Korea, Switzerland, Taiwan (Chinese Taipei) and the United Arab Emirates.

2. Middle East \& Africa: excludes unusually high port and rail data for Nigeria; including these data brings the total weighted average to 5.7 per cent.

3. Other: includes airport, water and telecommunications.

Source: McKinsey \& Company (2013).

There is ample evidence that the quality of infrastructure has an important effect on growth of the Indian manufacturing sector (Hulten et al., 2006; Sharma and Sehgal, 2010; Mitra et al., 2012; Sahoo and Dash, 2009, 2012). Better infrastructure improves connectivity, lowers transport costs and facilitates access to basic education and health services. The unequal distribution of infrastructure is an important explanation of diverging economic performance across states (Majumder, 2005; Purfield, 2006 and Agarwalla, 2011). Infrastructure development is also associated with reduced income inequality and can be a powerful tool for poverty reduction (López, 2004).

The Twelfth Five Year Plan, 2012-2017 foresees an increase in infrastructure investment to $8.2 \%$ of GDP (Table 3) and expects about half of investment to come from the private sector. However, despite increasing investment, progress has been disappointing. About $40 \%$ of the infrastructure projects commissioned during the last two five-year plans experienced huge delays (Ernst \& Young and FICCI, 2012), and resulted in cost overruns of more than 100\% (Table 4). Major causes of delays are related to the protracted process of land acquisition and securing environmental or various other clearances. Another cause of delays is frequent changes in the scope of projects by the authorities, which often lead to protracted disputes between government agencies and contractors. 
Table 3. Investment in infrastructure in India

\begin{tabular}{|c|c|c|c|}
\hline \multicolumn{4}{|c|}{$\%$ of GDP } \\
\hline Sectors & $\begin{array}{l}\text { Tenth Plan } \\
(2002-07)\end{array}$ & $\begin{array}{c}\text { Eleventh Plan } \\
(2007-12)\end{array}$ & $\begin{array}{c}\text { Twelfth Plan - } \\
\text { planned }(2012-17)\end{array}$ \\
\hline Electricity & 1.5 & 2.4 & 2.7 \\
\hline Roads and Bridges & 0.8 & 1.3 & 1.3 \\
\hline Telecommunications & 0.8 & 1.1 & 1.4 \\
\hline Railways & 0.6 & 0.7 & 0.9 \\
\hline Ports & 0.1 & 0.1 & 0.3 \\
\hline Airports & 0.0 & 0.1 & 0.1 \\
\hline Other $^{1}$ & 1.1 & 1.3 & 1.3 \\
\hline Total & 5.0 & 7.2 & 8.2 \\
\hline Public & 3.9 & 4.6 & 4.2 \\
\hline Private & 1.1 & 2.6 & 3.9 \\
\hline
\end{tabular}

1. Other includes Oil and Gas Pipelines, Irrigation, Storage and Water Supply.

Source: The Planning Commission.

Table 4. Project status of 564 infrastructure projects as of May 2012

\begin{tabular}{lccc}
\hline & $\begin{array}{c}\text { Number of } \\
\text { Projects Delayed }\end{array}$ & $\begin{array}{c}\text { Delay Period } \\
\text { (in Months) }\end{array}$ & $\begin{array}{c}\text { Cost escalation } \\
\text { (in percentage) }\end{array}$ \\
\hline Roads \& Transport & 78 & $2-101$ & 8 \\
Power & 47 & $1-83$ & 12 \\
Oil \& Gas & 31 & $4-120$ & 10 \\
Railways & 27 & $2-204$ & 137 \\
Urban & 1 & 24 & 82 \\
Coal & 17 & $9-48$ & 27 \\
Shipping \& Ports & 10 & $2-93$ & 10 \\
\hline
\end{tabular}

Source: Ernst \& Young and FICCI (2012).

In recognition of the problems, the government in December 2012 set up the Cabinet Committee on Investment (CCI) to fast track large infrastructure projects involving investment worth INR 10 billion (EUR 120 million) or more. The objective of the CCI is to facilitate land acquisition and approvals and clearances (e.g. for the environment) by involving all ministries in the decision making process. The committee has already had some effect, and several projects received relatively quick approval in 2013. The new government is showing the same resolve and claims that it will closely track the progress of all projects to ensure that approvals translate into actual production activity on the ground. While the committee may facilitate granting of clearances, it is equally important that the bureaucratic process of securing various regulatory approvals and environmental clearances is simplified and that clearly defined timelines are imposed. 


\section{Unreliable power supply is a big constraint}

While energy demand has increased rapidly with economic growth, energy supply has been hampered by transmission and distribution (T\&D) losses, failure to increase coal extraction, and pricing policies resulting in financial problems and underinvestment. The International Energy Agency (IEA) Energy Development Index 2011 ranked India 34th out of 64 lower-income countries in terms of energy development, behind countries such as China, Brazil and Indonesia. At the national level, the average power supply deficit from FY 2009-10 to $2012-13$ was $8.9 \%$ and peak shortage stood at $10.5 \%$ (Central Electricity Authority). India compares very poorly to other countries on T\&D losses: they stand at over $20 \%$ compared to $6 \%$ in China (Figure 13 ).

Figure 13. Electric power transmission and distribution (T\&D) losses

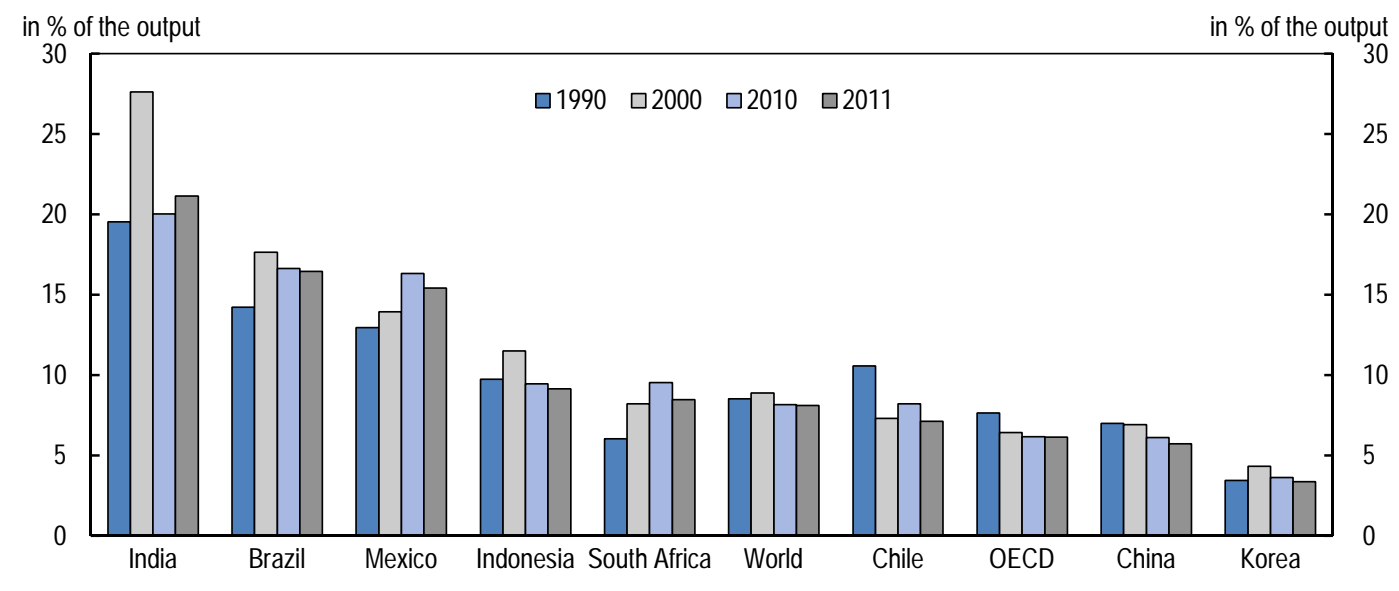

Source: World Bank Online Database.

The large power supply deficits experienced throughout the country are a key factor in electricity outages. In July 2012, the national transmission grid experienced two major blackouts that caused the northern half of the country to go without power for several hours. This imposes high costs on the economy through the need for high-cost backup generators and investment in self-generation facilities. Frequent power cuts are especially costly for manufacturing firms. A business survey finds that $48 \%$ of firms experience power cuts for more than 5 hours a week. About $60 \%$ of firms feel that erratic power supply affects their competitiveness and they would be willing to pay more for a more reliable supply (FICCI, 2012).

About two thirds of power generation comes from coal in domestic supply. In spite of large domestic coal reserves, the growing share of coal is imported underlining deficiencies. State-controlled Coal India Limited contributes around $80 \%$ of coal production. Coal supply is allocated through a cabinet committee, on a state-by-state basis. Private companies are restricted in their ability to obtain sites for coal mines and are allowed to mine coal only for captive use. Obtaining the required clearances for coal exploitation has been difficult recently, leaving many power plants short of coal. The situation was made worse in 2012 with a fraudulent scheme surrounding coal allocation that implicated many companies and top government officials. Imported coal increases costs for energy producers, as the regulated price of domestic coal is kept low (even after adjustment for its low calorific value). 
The government has proposed use of public-private partnerships (PPP) to finance coal mining. The current proposal stipulates that the mine and the coal will remain in public ownership while the private partner will receive a fee for the coal mined. In June 2013, the government approved a coal regulatory authority to specify the methodology for setting the coal price. It also allowed energy producers to pass on to consumers the higher price of imported coal that they buy to make up for domestic shortfalls. In November 2014, the government announced a plan to e-auction coal mines that were de-allocated after corruption scandals.

The precarious financial position of the state electricity boards (SEBs) and distribution companies has resulted in severe underinvestment, and is a factor discouraging new entry. Accumulated financial losses in the power sector amounted to 2.4\% of GDP in FY 2011-12 (PFC, 2013), accrued mostly by the distribution companies (World Bank, 2012). The losses arise primarily because state regulators hold tariffs below the cost of supply. There is also extensive cross-subsidisation in favour of agricultural and household users, and $24 \%$ of power is unmetered or stolen (McKinsey \& Company, 2013).

The central government approved a scheme in 2012 whereby $50 \%$ of the outstanding short-term liabilities of distribution companies is to be taken over by state governments and the remaining $50 \%$ is to be restructured. This restructuring has to be accompanied by concrete and measurable action by the states and distribution companies to improve their operational performance. The central government will provide incentives proportional to the reduction in T\&D as well as commercial losses (aggregate technical and commercial losses) and partial support with the repayment of the principal on the liabilities taken over by the state governments. The authorities should strictly monitor the implementation of the scheme, to ensure that aggregate technical and commercial losses are effectively reduced and tariffs are set adequately.

\section{Transport infrastructure sector suffers from long delays}

India's transport relies heavily on roads, whereas railway and waterways are underutilised. Roads infrastructure is poor and investments face huge delays. Railway projects face even longer delays and, with the Indian Rail organised as a ministry, the sector should be reformed. Ports are congested and are not adequately linked to their hinterlands.

Compared to China and the United States, India's freight transport relies heavily on roads (Figure 14). This is costly as $80 \%$ of freight (in ton- $\mathrm{km}$ ) is transported over distances of more than $400 \mathrm{~km}$, and could be more economically served by rail and waterways. Purchasing power parity adjusted costs show that rail is $70 \%$ more expensive and roads are 30\% more expensive in India as compared to the United States, pointing to much inefficiency (McKinsey \& Company, 2010). India should therefore shift to a more balanced modal network, with better developed rail network and waterways for long-distance transportation. As argued in McKinsey \& Company (2010), more funds should also be devoted to improve connectivity with ports, mines and industrial clusters and to facilitate better integration across different transport modes.

Roads carry $60 \%$ of freight and $85 \%$ of passenger traffic in India. National Highways carry $40 \%$ of the total road traffic, despite accounting for only $1.6 \%$ of the road network (Ernst \& Young and FICCI, 2012). Yet, the Global Competitiveness Report 2013-14 ranks India $84^{\text {th }}$ out of 148 countries by its quality of roads, worse than China and Indonesia. Only half of the roads are paved (World Road Statistics, 2012). The target was to build an average of 20 kilometres of highways per day, but in 2011-12 the actual progress dropped to $10.4 \mathrm{~km}$ a day (Ernst \& Young and FICCI, 2012). Investment in the sector faces huge delays, even in flagship projects such as the Golden Quadrilateral and the North-South-EastWest Corridor. 
Figure 14. Inland freight transport is overly dominated by roads (2009)

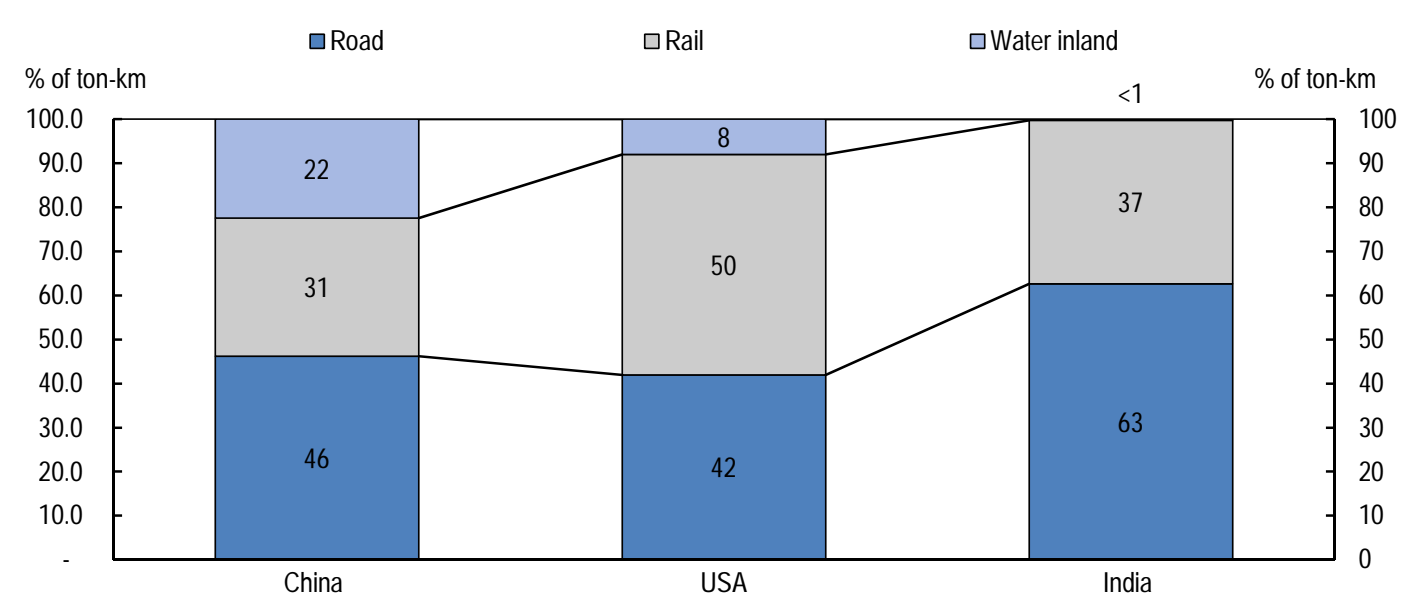

Note: The total freight transport by the three modes in 2009 was equal to 8,046 billion ton-km in China, 4,470 billion ton-km in the USA and 1,617 billion ton-km in India.

Source: OECD ITF Transport statistics.

Despite the limitations of the road sector, railways have been losing passenger and freight traffic to roads. Their share of freight has dropped from $86 \%$ in the 1950 s to $39 \%$ at present (Government of India, 2012). Railway projects face even longer delays and cost overruns than road projects (Table 4); overruns are often more than $100 \%$. Between 2006 and 2011, only $1750 \mathrm{~km}$ of new lines were added, versus $14000 \mathrm{~km}$ in China (Ernst \& Young and FICCI, 2012). Passenger rail fares have long been kept artificially low, resulting in cross-subsidisation from freight transport, raising the cost of rail transport for businesses, including manufacturing. In January 2013, an increase in passenger fares was announced in the face of fierce public opposition, and adjustments in railway fares have been linked to changes in fuel costs in 2014. Nevertheless, revenues of railways remain low, weighing on investment and maintenance. Finally, Indian Rail is organised as a Government Ministry and functions as a customer and regulator at the same time. Corporatising its operations would reduce the scope for political interference and conflicts of interest and would sharpen its commercial focus.

India has 13 major ports and 60 operational non-major ports. India's ports are congested, with average capacity utilisation at major ports of around $90 \%$ as compared to an international average of $70 \%$. Furthermore, major ports lag behind their international counterparts on key operating indicators (Ernst \& Young and FICCI, 2012). After a very disappointing performance in meeting the investment targets during the $11^{\text {th }}$ Plan, the $12^{\text {th }}$ Five Year Plan foresees an increase in investment in ports from 0.1 to $0.3 \%$ of GDP (Table 3). It expects $87 \%$ of the total investment to come from the private sector. Yet, ports suffer from many of the same problems of the other infrastructure sectors regarding long delays in land acquisition and clearances. All but one of the major ports are administered by the government. Furthermore, tariffs at major ports are set on a cost-plus basis that does not promote efficiency. Intra-port competition could be encouraged by granting multiple concessions to private operators at a single port. At the same time, the limitations of road and rail transport mean connectivity to ports' hinterlands is inadequate, pointing to the advantages of a comprehensive transportation infrastructure policy.

\section{Financing is difficult}

Infrastructure projects typically have a long gestation period and are highly capital intensive. A large part of infrastructure financing is now sourced through banks (City of London, 2012). However, banks' ability to extend long term loans for infrastructure is limited as they run the risk of serious asset-liability 
mismatches, and many are close to their prudential ceilings for exposure to the infrastructure sector and to a single borrower. Infrastructure is one of the sectors that account for highest share of stressed assets in banks (RBI, 2013). Similarly, most existing domestic developers are over-leveraged and their current cash flow does not permit raising any fresh debt for new projects.

Several initiatives have recently been launched to promote the flow of long-term funds into the infrastructure sector: setting up Infrastructure Debt Funds, raising foreign institutional investor (FII) limits for infrastructure and liberalising external borrowing limits. India has also attracted private capital in recent years. In the last five years, among the low and middle income countries, India has had the highest level of total investment in infrastructure projects with private participation; about $50 \%$ more than Brazil, the second ranked country (World Bank, 2014b). The central government has taken several policy and institutional initiatives to promote public private partnerships (PPP), but again structural and regulatory barriers - delays with land acquisition and various clearances as well as low commercial viability of infrastructure projects due to misaligned pricing - hinder the expansion of private financing.

Deregulating the financial sector and deepening bond markets would expand financing and bring in new investors. Equity markets in India are relatively well developed, but they are not favourable to the infrastructure sector due to long delays and current uncertainties in the global economy. The corporate debt market, on the other hand, is shallow and cannot provide enough long-term financing. Insurance companies and pension funds are required to invest substantial shares of their investible funds in government securities, and relaxing these restrictions would potentially free up funds for infrastructure. Similarly, foreign institutional investors face a cap on corporate bond holdings. Authorities should further deepen the corporate debt market by gradually relaxing the restrictions on domestic and foreign investors.

\section{Making land acquisition more efficient}

Lengthy and complex land acquisition processes are a major barrier for infrastructure development, and poor land title records make buying land difficult even for private purposes. Senior managers of manufacturing companies consistently rank difficulties in acquiring land as one of the top priority areas to be tackled by the government (CII-BCG, 2012; FICCI, 2011). Acquiring land can take up to three years even in the absence of resistance from local communities (Mahalingam and Vyas, 2011). For about $70 \%$ of the delayed infrastructure projects, land acquisition is the main cause of delay (IDFC and 3i Network, 2009; Ernst \& Young and FICCI, 2012). Government agencies responsible for PPP infrastructure projects often rush to offer projects for bidding, without first acquiring all of the required land, causing delays at later stages.

Difficulties in acquiring land partly reflect poor land-title records, and a reliable land registry system is urgently needed to ensure clear title to property. As pointed out in the previous Economic Survey (OECD, 2011), land records tend to be outdated, inaccurate and incomplete, and land title can be difficult to establish. Currently, details of property transactions are recorded but generally there is no guarantee as to whether the title is legitimate, causing excessive litigation. Moreover, there is no unified map of parcel boundaries. In 2008, the government launched the National Land Records Modernisation Programme (NLRMP), whereby each state government was expected to cover the entire state by 2017. The NLRMP would result in an up-to-date digital register of all land records, enhancing transparency and guaranteeing a conclusive land title. In many states, however, progress should be faster. The government has proposed a Land Titling Bill that will eventually result in a guaranteed title for all land parcels. The proposed bill follows best practice by separating policy, operations and regulation: each state will have to create a Title Authority, separate from the Land Ministry, and a Land Tribunal will be established to control decisions of the Authority with appeals possible to the High Court (Sinha, 2010). The Bill has not been passed yet. 
Inadequate compensation and poorly planned rehabilitation packages in acquiring land for public purpose have often created delays. Up to 2014, landowners were often compensated based on the registered value of their land, which is often much below market value, leading to resistance, disputes and litigation. This contrasts with the approach in the Philippines and Singapore where government agencies and developers first negotiate with stakeholders to arrive at a mutually acceptable compensation package and thereby gain trust of the local communities. If such negotiations fail, the agencies then resort to acquisition based on predetermined legal formulae (Mahalingam and Vyas, 2011).

To address the land acquisition issue, in September 2013 the parliament passed the Right to Fair Compensation and Transparency in Land Acquisition, Rehabilitation and Resettlement Bill, effective from 2014 (Box 4.). In rural areas, landowners are to receive compensation of up to four times the market value of the land. While the Bill will increase the direct cost of land acquisition, it is expected to reduce indirect costs as the incidence of disputes and litigation should decline. However, the process of acquiring land can still be very protracted. Even excluding possible delays due to disputes, it can take 50 months under the new Bill. The implementation of the law in practice should be closely monitored and where there are weaknesses, the law should be amended as needed. The government should review the timelines established by the Bill and aim to make land acquisition faster. The institutional set-up should allow for swift resolution of disputes.

\section{Box 4. The Right to Fair Compensation and Transparency in Land Acquisition, Rehabilitation and Resettlement Bill}

The act establishes the law on land acquisition, as well as the rehabilitation and resettlement (R\&R) of those directly affected by land acquisition in India. This act was passed by both houses of the parliament and signed by the President of India in September 2013 and came into force on January $1^{\text {st }}, 2014$. It replaces the Land Acquisition Act, 1894, a more than 100 year-old law from the British era.

The Act is applicable when land is acquired for public purpose. The government can acquire land for its own use, or for public private partnership projects, where the ownership of the land stays with the government, or when it acquires land for use of private companies. The public purpose includes defence and national security, infrastructure projects including for mining, industrial zones, roads, railways, highways, ports, and projects for sports, health care etc.

In the case of acquisition for private companies and for public private partnership, the prior consent of at least $80 \%$ and $70 \%$ of the affected families, respectively, must be obtained. When the government acquires land directly for its own use, consent of the land owner is not required. Importantly, the purchase of land by private companies of sizes beyond a certain threshold will also require provision of R\&R as stipulated by the law. The threshold is left to the discretion of state governments.

The process of land acquisition shall involve a Social Impact Assessment (SIA) survey, conducted in consultation with local authorities. The SIA survey shall include an assessment whether the proposed acquisition serves public purpose, estimation of affected families and extent of lands, houses and settlements likely to be affected by the proposed acquisition, and a study of social impact of the project.

The Act proposes the total minimum compensation to the land owners to be at least two times the market value for land acquired in urban areas and up to four times in rural areas, the multiplier having been left to the discretion of state governments and is expected to rise with the distance from urban areas. In addition to the compensation, the Act proposes a wide range of $R \& R$ entitlements to land owners and other livelihood losers. Furthermore, land owners and livelihood losers are entitled to subsistence allowance for one year, a new house if a house is lost, and a choice of either money reward, annuity for 20 years or employment for each affected family. Every resettled area is to be provided with certain infrastructural facilities, such as roads, drainage, drinking water etc. Finally, the land can be taken into possession only after ensuring that the compensation and R\&R responsibilities have been discharged.

In each state, a Land Acquisition and Rehabilitation and Resettlement Authority shall be established for settling any disputes relating to the process of acquisition, compensation, and R\&R. Moreover, monitoring committees will be established to ensure that R\&R obligations are met. 


\section{Reforming taxation}

\section{The complexity and uncertainty surrounding the tax system discourage investment}

The complexity of the tax system and frequent changes in tax laws have undermined activity. The World Bank ranks India 156 out of 189 countries in the 2014 "Ease of Paying Taxes". The overall effective tax rate for small to medium sized companies is relatively high, in particular the corporate income tax, and so are compliance costs and time (Figure 15). Tax disputes have been frequent, involving for example the definition of what constitutes a service and should thus be subject to the Service Tax rather than the VAT. Uncertainty over tax reliefs for Special Economic Zones (SEZs) has also led to a declining interest in those enclaves; a recent business survey revealed that $62 \%$ of the respondents had suspended plans to invest further in SEZs as a result of the 2011 introduction of a Minimum Alternate Tax and Dividend Distribution Tax for firms settled in SEZs (Ipsos, 2013). ${ }^{2}$ The Direct Tax Code Bill, pending since 2010, envisages replacing income tax holidays by complete first-year depreciation for investment in SEZs' companies established from 2014 onwards. This proposal, if adopted, will bias the tax towards capital-intensive investment projects. The multiplication of special tax regimes and frequent changes in tax laws should be avoided to support business investment. Tax cascading and high tariffs inflate costs and hamper participation in global value chains.

The indirect tax system is complex, costly to comply with and puts India's manufacturing sector at a competitive disadvantage on international markets. Tax cascading - not all indirect taxes on inputs can be deducted from indirect taxes on outputs and taxes-on-taxes are due - has been reduced since the mid-2000s with the replacement of state-level sales taxes by state-level value added taxes (Box 5). However, cascading remains sizeable and inflates production costs by $10 \%$ to $15 \%$ for manufacturing companies according to the Indian Institute of Corporate Affairs (2011). Inter-state trade is discouraged by taxes on inter-state movement of goods (central sales tax (CST), entry tax, etc.), combined with excessive queues and multiple inspections associated with cross-state trade in goods.

The manufacturing sector suffers most from the complexity of indirect taxes and from tax cascading since the production process tends to involve more inputs and transactions than services (OECD, 2012) and the taxation of services is thus much less fragmented in practice (Keen, 2013). ${ }^{3}$ Tax cascading encourages manufacturers to integrate vertically, thus partly explaining why some firms in India are very large. Tax cascading also encourages manufacturers to source inputs from the same state or to import from abroad since imports do not bear the hidden burden of taxes on inputs. Imports are however subject to tariffs and non-tariff barriers (see below).

2. From FY 2011, the government imposed a 18.5\% Minimum Alternate Tax (MAT) on firms settled in SEZs with no taxable income but showing book profits while the SEZ Act promised 100\% tax exemption for 5 years and $50 \%$ exemption for the next 5 years.

3. OECD (2012), Mapping Global Value Chains, $\underline{T A D / T C / W P / R D(2012) 9}$, Figure 4. 
Figure 15. Complying with the tax system is relatively costly
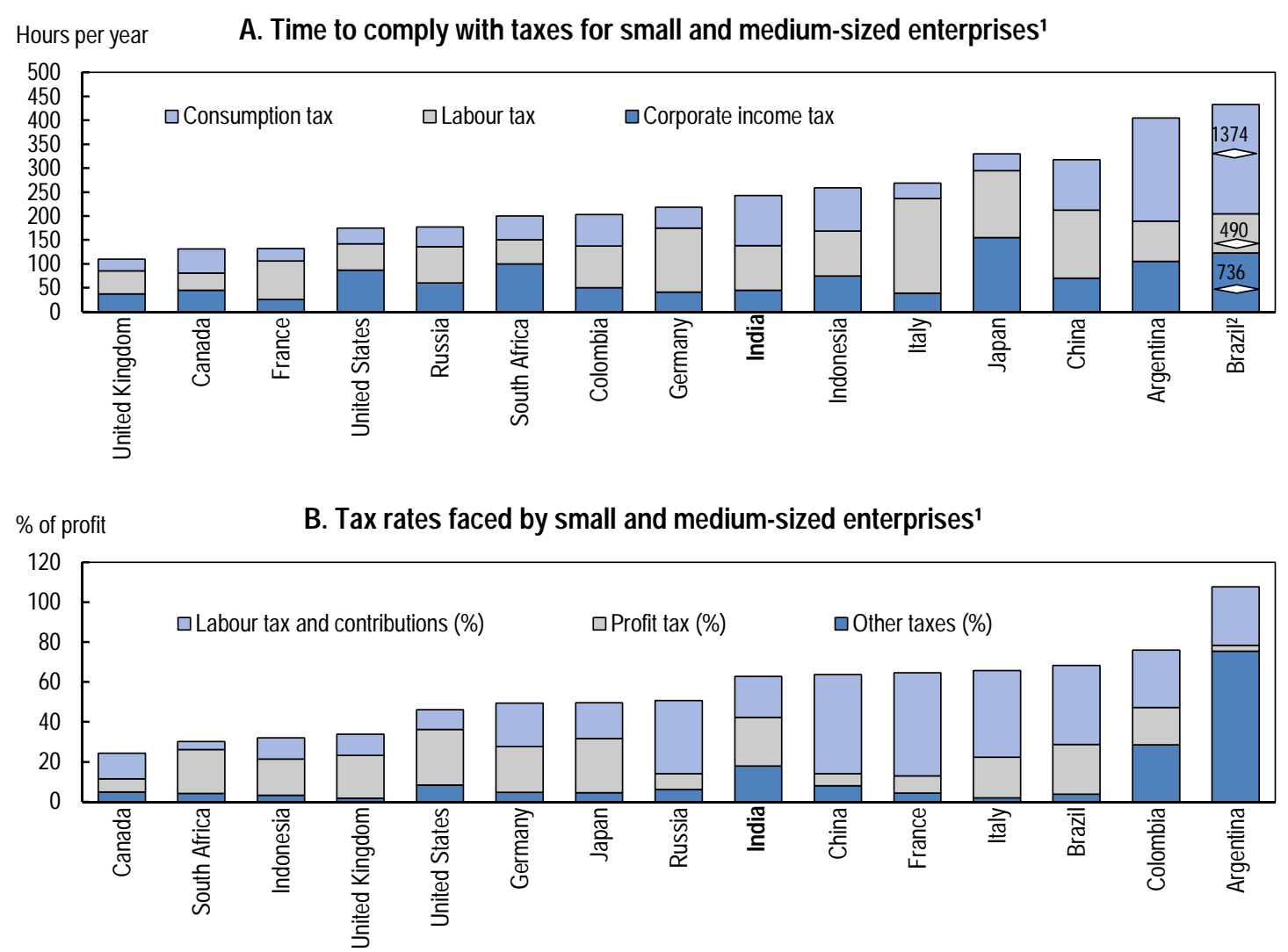

1. The Paying Taxes study refers to a standardised small and medium-sized enterprise, with 60 employees. Taxes and contributions include the profit or corporate income tax, social contributions and labour taxes paid by the employer, property taxes, dividend tax, capital gains tax, financial transaction tax and any other small taxes and fees. Value added taxes are generally excluded when calculating the tax rate. The data shown here should be treated with caution as the use of a single hypothetical entity as the basis for computing the costs of compliance may be flawed.

2. Brazil's values regarding time to comply with taxes for small and medium-sized enterprises are not shown on scale, however, the corresponding values are indicated.

Source: PWC Paying Taxes, 2014 Report; and IFC and WB Doing Business database, Paying Taxes section.

Competitiveness and growth of the manufacturing sector would be raised by introducing the GST and reducing tariffs and non-tariff barriers. The GST is expected to lift GDP by 0.9 to $1.7 \%$ according to the NCAER (2009) and CII (2012). The NCAER study further suggests that it would benefit most the manufacturing sector, in particular textile industries, and make exports more competitive. To get the most out of the GST, it would be important to avoid the use of exemptions, reduced rates and other preferential regimes. To address social concerns and alleviate poverty (e.g. to compensate for the cost of more expensive food products for the poor), relying on direct and targeted cash transfers should be given priority in the short run. In the longer run however, a social safety net should be put in place to protect the poor from tax changes and other economic shocks. Reducing both the average level and the dispersion in tariff rates and streamlining trade procedures would also help to promote robust supply chains and competitiveness of the manufacturing sector. 


\section{Box 5. The system of indirect taxes}

\section{Main features of existing indirect taxes}

Various indirect taxes are levied by both the central government and sub-national governments, with taxing rights enshrined in the Constitution:

- The central government has the right to tax the production of goods through the so-called Central Value Added Tax (CENVAT) (standard rate of 12\%, with two reduced rates: 6 and $0 \%$, on presumptive retail values with a credit for taxes paid on inputs), but not the sale of goods. Interstate sales are the exception: they are subject to the $2 \%$ central sales tax (CST) with the proceeds accruing to the state where the good originates. The central government also levies a $12 \%$ Service tax, which cannot be deducted from indirect taxes levied by state governments. Custom duties and other taxes on imports/exports are set and collected by the central government. A $3 \%$ surcharge - earmarked for specific spending - is imposed on all central taxes (e.g. the 12\% Service tax rate becomes $12.36 \%)$.

- The states can tax goods within their boundaries at all stages but cannot tax services (except a limited number of specified services, such as entertainment and gambling). The main indirect tax they imposed is a VAT on goods, introduced in 2005 to replace the states' sales tax. Some VAT rates vary across states, though within a small range. A tax credit is available for prior-stage state VAT, but not for the CENVAT and the CST. States also levy various other taxes, including: stamp duties on the purchase of immovable property and various other transactions; profession taxes; a luxury tax; and duties on electricity.

- Local bodies and municipalities levy a tax on the entry of goods within their jurisdiction at a rate of 1 to $13 \%$ on the value of goods.

- Beyond these general taxes, the central and state governments collect a vast array of revenue and stamp duties which resemble cascading turnover taxes (Cnossen, 2012).

Tax cascading has been reduced since the mid-2000s with the replacement of states' sales taxes by VAT on goods. Some cascading remains however since not all indirect taxes paid on inputs can be deducted from taxes on outputs. In particular, once goods leave the factory, the central VAT on manufacturing becomes an excise tax and so is not subject to rebate at the state level. The tax on inter-state trade (CST) has been reduced from 4 to $2 \%$ but no credit for this tax is allowed by any level of government. Exempt sectors also contribute to the cascading effect since these sectors cannot claim for a tax credit for the tax paid on inputs. In particular, all services, real property, agriculture, oil and gas production, and mining are exempt from state VAT. The Service tax falls predominantly on business to business (B2B) services and is thus highly cascading in nature (Poddar and Ahmad, 2009).

Replacing the complex system of indirect taxes with a comprehensive value added tax has been considered for more than 20 years (Chelliah Report, 1992) to reduce administrative costs, improve tax compliance, make India a single market and promote competitiveness. A Constitution Amendment Bill introduced in Parliament in 2011 seeks to replace the CENVAT and the Service tax (both levied by the central government) and the VAT levied by the States by a Goods and Services Tax (GST). The Bill would introduce a dual GST, with both a central government component (CGST) and a state component (SGST) to be administered separately, with a proposed standard rate of $8 \%$ each. Inter-state and cross-border transactions would be subject to the Integrated GST (IGST). IGST would apply in the state of the supplier but the central government would operate a clearinghouse and compensate the consuming state according to the destination principle (OECD, 2012).

In designing the GST, a trade-off between simplicity and fiscal autonomy for the states has to be recognised (Rao, 2011). While implementing identical SGST rates and bases (in particular exemptions) would contribute to keeping administrative and compliance costs low, this would reduce states autonomy. One option considered would be to give states the right to set the rates within a band on the SGST. 
The draft Bill explicitly excludes some goods from the GST, in particular petroleum products, despite the recommendations of the $13^{\text {th }}$ Finance Commission (chaired by Dr Kelkar). Some tax cascading will thus remain since petroleum products are inputs for many goods and services. It is also quite likely that some discretion in defining exemptions will be allowed to individual states.

Implementing the GST requires amending the Constitution, which could be done only if each House of Parliament approves it by $2 / 3$ majority and if it is ratified by at least 14 (out of 28) state legislative assemblies. Reaching a consensus may be difficult as many state governments have expressed concerns about revenue loss, fiscal autonomy and lack of GST infrastructure (Vaidya and Kanagasabapathy, 2013). Meanwhile, the central government has implemented a number of reforms to improve the design and operation of its existing indirect taxes, with a view to facilitating the introduction of the dual GST. These reforms notably involve some tax rate simplification and broadening tax bases, the harmonisation and simplification of specific design features of these taxes (e.g. alignment of exemptions and place of taxation provisions) and some simplification of compliance requirements (e.g. harmonised tax returns).

High import tariffs and non-tariff barriers also hinder the productivity and competitiveness of the manufacturing sector. Recent OECD work reveals how global value chains (GVCs) magnify the costs of tariff protection since tariffs are cumulative when intermediate inputs are traded across borders multiple times. India's foreign value added content of exports amounted to $22 \%$ in 2009 , the second highest in the BRIICS after China, up from 10\% in 1995, illustrating an increased fragmentation of production, and integration in GVCs. India participates strongly in manufacturing GVCs for chemicals and electrical equipment. Tariffs have been cut significantly in India since the early 1990s, relaxing technological constraints through firms' access to new imported inputs (Goldberg et al., 2008). More recently, India has given priority to signing Free Trade Agreements. Since the early 2000s, eight FTAs have been signed with South Korea, Sri Lanka, Singapore, Japan, Malaysia, Thailand, South Asia and ASEAN countries. FTA negotiations have been launched with Australia, Canada the EU, Israel, New Zealand and MERCOSUR countries.

However, tariffs remain high compared to other BRICs and OECD countries which, given the growing importance of imports for exports in global value chains, hampers the productivity and competitiveness of the manufacturing sector. An OECD study suggests that a 10 percentage point increase in the share of imported intermediate inputs is associated with about $0.5 \%$ increase in labour productivity in emerging economies (OECD, 2013). The very high bound rates could further create uncertainty for manufacturers and discourage investment as tariffs can be raised without contravening WTO conventions. In practice, however, India's indirect taxes operate effectively through a system of notifications and peak rates for non-agriculture products have been brought down since 1991.

India also imposes non-tariff barriers in the form of quantitative restrictions, import licensing, burdensome mandatory testing and certification for a large number of products, as well as complicated and lengthy customs procedures (European Commission, 2011). India ranks $132^{\text {nd }}$ out of 189 countries in the Ease of Trading across Borders (World Bank, 2014a), partly reflecting the number of documents required to import and export and the related time to get them. The OECD Trade Facilitation Indicators (Figure 16) suggest that India performs better than the averages of Asian and lower-middle income countries in a number of areas (including information availability and border agency cooperation). However, India could draw considerable benefits in terms of trading costs and trade volumes from reducing fees and charges and streamlining procedures (OECD, 2013). 
Figure 16. OECD indicators on trade facilitation performance show mixed results for India

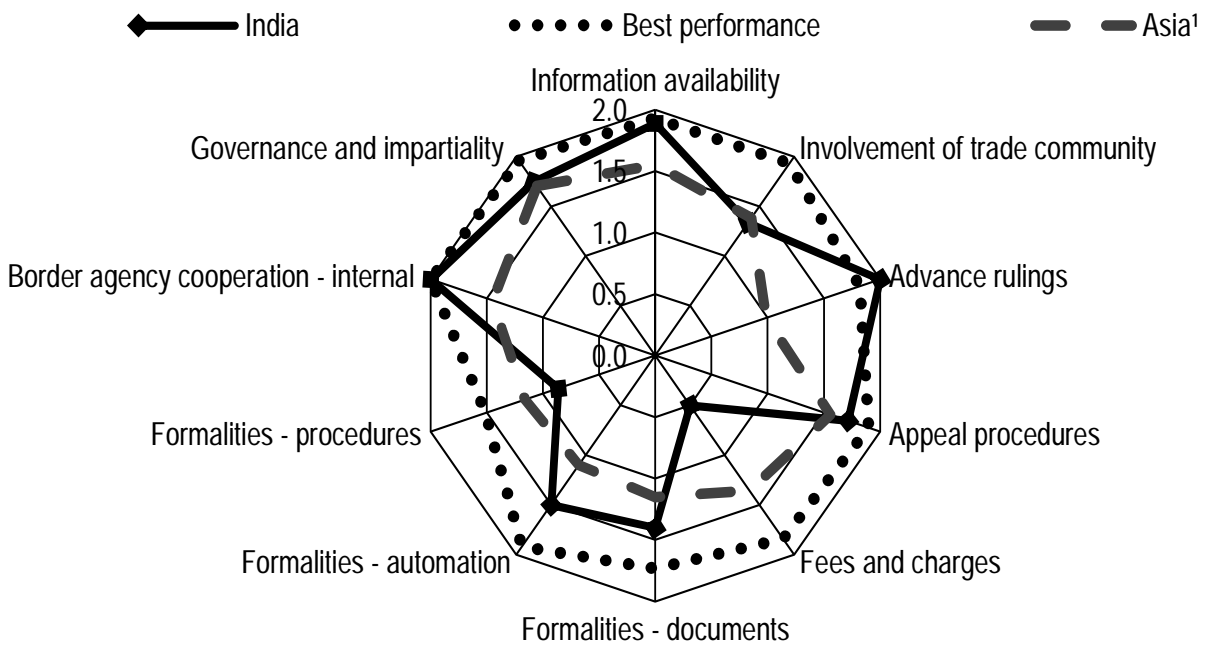

Note: For India, insufficient reliable information is available at this stage for indicator 'Border agency cooperation - external'. The analysis is based on the latest available data as of January 2013 and the set of TFIs as constructed in "Trade Facilitation Indicators: The Potential Impact of Trade Facilitation on Developing Countries' Trade" (OECD Trade Policy Paper No. 144, 2013). "Best performance" denotes the average of the top quartile for each of the trade facilitation areas covered, across all countries within the database.

1. Average for: Bangladesh, Fiji, Mongolia, Singapore, Brunei Darussalam, Hong Kong, Nepal, Sri Lanka, Cambodia, India, Pakistan, Thailand, China, Indonesia, Papua New Guinea, Vietnam, Chinese Taipei, Malaysia, Philippines.

Source: OECD Trade facilitation indicators database. 


\section{Recommendations to raise employment creation and value added from the manufacturing sector}

\section{Key recommendations}

- $\quad$ Reduce barriers to formal employment by introducing a simpler and more flexible labour law which does not discriminate by size of enterprise.

- Continue improving access to education, especially at the secondary level, and improve the quality of education. Provide better and earlier vocational training.

- In the infrastructure sector, impose clear timelines, rationalise documentation, and implement single-window clearance.

- Continue improving the business environment and opening up the economy.

\section{Further recommendations}

\section{Labour market}

- Improve the timeliness, quality and consistency of labour market data.

\section{Education and training}

- $\quad$ Better monitor learning outcomes and track implementation of reforms. Strengthen dismissal provisions for teachers who are repeatedly absent or are not performing satisfactorily. Improve training of teachers.

- Include industry demand and skill requirements in designing vocational education and on-the-job training, and update curricula every two to three years. Consider government sponsored voucher schemes and government loan guarantees to increase access to vocational education.

\section{Infrastructure}

- $\quad$ Simplify the bureaucratic process of securing regulatory approvals and environmental clearances. Define timelines for all stages of granting approvals and rely more on single window clearance mechanisms.

- Monitor and implement the financial restructuring of the state electricity distribution companies. Make the provision of electricity economically viable by raising tariffs. Make sure that consumers are billed for electricity based on the usage by widening the use of metering.

- Improve competition and efficiency in the coal sector. Market-based pricing and allocation should play a larger role and could attract more private investors.

- $\quad$ Allocate a higher proportion of funds to rail, as opposed to roads.

- Set up the Railways Tariff Regulatory Authority. Corporatise India Rail and unbundle regulatory, policymaking, and ownership functions. Increase tariffs for passengers further to be more in line with costs.

- Tariff-setting process at ports should move away from a cost-plus basis to encourage productivity improvements. Grant multiple concessions to private operators at a single port to increase competition.

- $\quad$ Ease investment allocation restrictions imposed to pension and insurance funds to enable more investments in the infrastructure sector. 


\section{Land acquisition}

- Establish a reliable land registry to ensure clear title to property.

- Monitor and, as needed, amend the land acquisition law. Review the timelines within the Act to make land acquisition faster.

\section{Taxes and tariffs}

- The Goods and Services Tax should be implemented swiftly to promote solid value chains in the manufacturing sector and competitiveness of the Indian economy.

- $\quad$ Frequent changes and retrospective amendment in tax laws should be avoided to support business investment. Special tax regimes should be streamlined to simplify the tax system, reduce compliance and collection costs and reduce tax avoidance. Tax breaks in special economic zones should not create a bias towards capital intensive projects.

- Gradually move towards a uniform tariff rate for all non-agricultural products and streamline border procedures to reduce trade costs, boost trade flows and reap greater benefits from international trade. 


\section{BIBLIOGRAPHY}

Agarwalla, A. (2011), "Estimating the Contribution of Infrastructure in Regional Productivity Growth in India", Indian Institute of Managament, Ahmedabad, Working Paper no. 2011-05-01, May 2011.

Belser P. (2013), "Wages in developing countries", in Perspectives on Labour Economics for Development, (Cazes and Verick ed.), ILO.

Besley T and R. Burgess (2004). "Can Labor Regulation Hinder Economic Performance? Evidence from India," The Quarterly Journal of Economics, MIT Press, vol. 119(1), pages 91-134, February.

Bhagwati J. and A. Panagariya (2013), Why Growth Matters, Public Affairs Book.

Bhattacharjea A. (2009), "The Effects of Employment Protection Legislation on Indian Manufacturing", cddrl Working Papers , No. 96, January.

$\mathrm{http}: / /$ cddrl.stanford.edu/publications/the_effects_of_employment_protection_legislation_on_indian -manufacturing

Chelliah R. J. et al. (1992), Final Report of the Tax Reforms Committee, Indian Ministry of Development.

CII \& BCG (2012) “Re-igniting India's quest for manufacturing leadership”, CII 11th Manufacturing Summit.

City of London (2012), "Indian Infrastructure 2010-2012: Review”, September. http://www.cityoflondon.gov.uk/business/support-promotion-and-advice/promoting-the-cityinternationally/india/Documents/Indian\%20Infrastructure\%20review\%20paperSept2012.pdf

Cnossen, S., 2012, “Introducing a Modern GST in India: Need for Further Debate," Tax Notes International, June.

Das, D.K., Erumban, A. A., Aggarwal, S. and Sengupta, S. (2014)," Productivity Growth in India under Different Policy Regimes: 1980-2012. Presentation made at the 3rd World KLEMS conference 2014, Tokyo, 2014.

Dougherty, S., V. Frisancho Robles and K. Krishna (2011), "Employment Protection Legislation and Plant-Level Productivity in India", OECD Economics Department Working Papers, No. 917, OECD Publishing. doi: $10.1787 / 5 \mathrm{~kg} 0 \mathrm{ndktrx} 46$-en

Ernst \& Young and FICCI (2012), "India Infrastructure Summit 2012: Accelerating implementation of infrastructure projects".

European Commission (2011), "Report from the Commission to the European Council -- Trade and Investment Barriers Report 2011. http://trade.ec.europa.eu/doclib/docs/2011/march/tradoc_147629.pdf 
Farole, Thomas (2011). "Special Economic Zones: What Have We Learned?," World Bank - Economic Premise, The World Bank, issue 64, pages 1-5, September.

FICCI (2011), FICCI's Business Confidence Survey, August 2011, FICCI (Federation of Indian Chambers of Commerce \& Industry).

FICCI (2012), "Lack of affordable \& quality power: shackling India's growth story", FICCI (Federation of Indian Chambers of Commerce \& Industry).

Gandullia L., N. Iacobone, A. Thomas (2012), "Modelling the Tax Burden on Labour Income in Brazil, China, India, Indonesia and South Africa", OECD Taxation Working Papers, No. 14, OECD Publishing.

Goldberg P. K., A. Khandelwal, N. Pavcnik and P. Topalova (2008), "Imported Intermediate Inputs and Domestic Product Growth: Evidence from India", NBER Working Paper No. 14416.

http://www.nber.org/papers/w14416

Government of India (2012), The Working Group Report on Road Transport for the Eleventh Five Year Plan, Government of India, Planning Commission.

Gupta, P., Hasan, R. and Kumar, U. (2008) “What constraints Indian manufacturing?”, ERD Working Paper No. 119, Asian Development Bank.

Hasan, R. and Jandoc, K.R.L. (2012) "Labor Regulations and the Firm Size Distribution in Indian Manufacturing". Columbia Program on Indian Economic Policies, Working Paper No. 2012-3 $\mathrm{http}$ //indianeconomy.columbia.edu/sites/default/files/working_papers/wp_2012-3.pdf

Hasan R., Mitra, D. and Sundaram, A. (2012) "What explains the high capital intensity of Indian manufacturing?" Indian Growth and Development Review, vol 6, Issue 2.

Hulten, C., Bennathan, E. and Srinivasan, S. (2006), "Infrastructure, Externalities, and Economic Development: A Study of the Indian Manufacturing Industry", The World Bank Economic Review, vol. 20, no. 2, 291-308.

IDFC (Infrastructure Development Finance Company) Foundation (2013), India Infrastructure Report 2012: Private Sector in Education. Routledge.

IDFC (Infrastructure Development Finance Company), 3 i Network (2009) India Infrastructure Report 2009: Land - A Critical Resource for Infrastructure. Oxford University Press, http://www.idfc.com/pdf/report/IIR-2009.pdf

Indian Institute of Corporate Affairs (2011), "GST and development of single national market". http://www.iica.in/images/GST\%20Single\%20National\%20Market.pdf

Ipsos (2013), "Minimum Alternate Tax on SEZs Has De-Rated India as an Investment Destination", Ipsos Survey, February.

Kapoor, R. (2014), “Creating Jobs in India’s Organised Manufacturing Sector”, ICRIER Working Paper, No. 286. http://icrier.org/pdf/Working_Paper_286.pdf 
Keen, M. (2013), “Targeting, Cascading, and Indirect Tax Design” IMF Working Paper No. 13/57, February.

Kochhar K, U. Kumar, R. Rajan, A. Subramanian and I. Tokatlidis (2006), "India's pattern of development: What happened, what follows?" Journal of Monetary Economics, Vol. 53, Issue 5, July 2006, pp. 981-1019.

Koske, I., J. Fournier and I. Wanner (2012), "Less Income Inequality and More Growth - Are They Compatible? Part 2. The Distribution of Labour Income", OECD Economics Department Working Papers, No. 925, OECD Publishing, Paris. doi: $10.1787 / 5 \mathrm{k} 9 \mathrm{~h} 2975 \mathrm{rhhf}-\mathrm{en}$

Kumar, K. B. and Liu, Y. (2008), “China and India, Different educational paths toward prosperity”, Policy Insight, RAND, Pardee Rand Graduate School, Volume 2, Issue 1.

Kumar, V. (2012). "Labour Laws: Are they holding back manufacturing sector growth and employment in India?". In Malhotra, R. (eds) A critical decade: Policies for India's Development. Oxford University Press, pages 376-403.

López, H. (2004), "Macroeconomics and Inequality", The World Bank Research Workshop, Macroeconomic Challenges in Low Income Countries, October, Washington, D. C.

Mahalingam, A. and Vyas, A (2011), "Comparative Evaluation of Land Acquisition and Compensation Processes" Economic and Political Weekly, Vol. XLVI, No. 32.

Majumder, R. (2005), “Infrastructure and Regional Development: Interlinkages in India”, Indian Economic Review, Vol. 40, No. 2, pp. 167-184.

McKinsey \& Company (2010), "Building India: Transforming the nation's logistics infrastructure", Infrastructure Practice, McKinsey \& Company.

McKinsey \& Company (2013), "Infrastructure productivity: How to save \$1 trillion a year", McKinsey Global Institute, McKinsey Infrastructure Practice.

Mehrotra S., S. Sinha, J.K. Parida and A. Gandhi (2014), "Why a jobs turnaround despite slowing growth?", IAMR Occasional Paper No1/2014.

Ministry of Finance (2014), "Industrial Performance", chapter 9 in the Economic Survey 2013-14, Government of India, New Delhi.

Ministry of Finance (2013a), "International Trade", chapter 7 in the Economic Survey 2012-13, Government of India, New Delhi.

Ministry of Finance (2013b), "Industrial Performance", chapter 9 in the Economic Survey 2012-13, Government of India, New Delhi.

Ministry of Finance (2013c), "Human Development" chapter 13 in the Economic Survey 2012-13, Government of India, New Delhi.

Ministry of Finance (2013d), "Seizing the demographic dividend", chapter 2 in the Economic Survey 201213, Government of India, New Delhi. 
Mishra, P. (2013), Has India's Growth Story Withered? Ministry of Finance, Government of India. http://www.prachimishra.net/potential_india_draft_revised_feb2013_sub.pdf

Mitra, A., Sharma, C. and Véganzonés-Varoudakis. M. (2012), "Estimating impact of infrastructure on productivity and efficiency of Indian manufacturing", Applied Economics Letters, 19, 779-83.

NCAER (2009), "Moving to Goods and Services Tax in India: Impact on India's Growth and International Trade", Prepared for the Thirteenth Finance Commission Government of India http://www.ncaer.org/Downloads/WorkingPapers/wp103.pdf

OECD (2014), OECD Territorial Reviews: Ukraine 2013, OECD Publishing, Paris. doi: $10.1787 / 9789264204836$-en

OECD (2013), “OECD Trade Facilitation Indicators - India”, OECD Publishing, Paris. www.oecd.org/tad/facilitation/india-oecd-trade-facilitation-indicators-april-2014.pdf

OECD (2012), "VAT and GST systems in federal countries", Chapter 7 in Consumption Tax Trends 2012, http://pac-files.oecd.org/acrobatebook/2312291e.pdf

OECD (2011a), OECD Economic Surveys: India 2011, OECD Publishing, Paris. doi: 10.1787/eco_surveys-ind-2011-en

OECD (2011b), Divided We Stand: Why Inequality Keeps Rising, OECD Publishing, Paris. doi: 10.1787/9789264119536-en

OECD (2010), Learning for Jobs, OECD Reviews of Vocational Education and Training, OECD Publishing, Paris. doi: $10.1787 / 9789264087460$-en

OECD (2007), OECD Economic Surveys: India 2007, OECD Publishing, Paris.. doi: 10.1787/eco_surveys-ind-2007-en

Papola (2013), "Labour Market Segmentation in India: Role of Regulation and Reforms", mimeo, presented workshop at ILO Geneva, 10-11 December 2012.

http://www.ilo.org/ifpdial/events/conferences/WCMS_195933/lang--en/index.htm

PFC (2013), “Report on the performance of state power utilities for the years 2009-10 to 2011-12”, Power Finance Corporation Ltd.

Planning Commission (2013), Twelfth Five Year Plan (2012-2017), Social Sector, Volume III.

Planning Commission (2011), "The Manufacturing Plan: Strategies for Accelerating Growth of Manufacturing in India in the 12th Five Year Plan and Beyond", Report of the Industry Steering Committee for the Twelfth Five Year Plan (2012-2017).

Poddar S. and E. Ahmad (2009), "GST Reforms and Intergovernmental Considerations in India", Government of India, Ministry of Finance, Department of Economic Affairs, Working paper 1/2009. http://www.lse.ac.uk/asiaResearchCentre/_files/ARCWP26-AhmadPoddar.pdf

Purfield, C. (2006), “Is Economic Growth Leaving Some States Behind?”, India goes global: Its expanding role in the world economy, IMF, Washington, D.C. 
Rao G. (2011), “Goods and Services Tax: A Gorilla, Chimpanzee or a Genus like Primates ?”, Economic and Political Weekly, Feb. 12, 2011.

RBI (2014), Annual Report 2013-2014, Reserve Bank of India, August 2014. http://rbidocs.rbi.org.in/rdocs/AnnualReport/PDFs/RBIARE210814_FULL.pdf

RBI (2013), Financial Stability Report, Reserve Bank of India , Issue 7, December. http://rbidocs.rbi.org.in/rdocs/PublicationReport/Pdfs/FSRDEC301213_FL.pdf

Sahoo, P. and Dash, R. K. (2009), "Infrastructure development and economic growth in India", Journal of the Asia Pacific Economy, Vol. 14, No. 4, 351-65.

Sahoo, P. and Dash, R. K. (2012), "Economic growth in South Asia: Role of infrastructure", The Journal of International Trade \& Economic Development, Vol. 21, No. 2, 217-52.

Sharma, C. and S. Sehgal (2010), "Impact of Infrastructure on Output, Productivity and Efficiency: Evidence from the Indian Manufacturing Industry", Indian Growth and Development Review, Vol. 3, No. 2.

Sinha, R. (2010), "Draft Land Titling Bill, 2010 - India", Presentation to a workshop on "The Fundamental Principles of Property Titling", July, New Delhi.

UNIDO (2013), Competitive Industrial Performance Report 2012/2013. The Industrial Competitiveness of Nations: Looking back, forging ahead, United Nations Industrial Development Organization.

Vaidya D. S. and K. Kanagasabapathy (2013), "Reform of Indirect Taxes -Hurdles before the GST", Economic and Political Weekly, June, Vol. 48, Nos 26 \& 27.

WIOD (2012): "World Input-Output Database (WIOD): Contents, Sources and Methods", Edited by Marcel Timmer (University of Groningen), Version 0.9, April.

World Bank (2014a), Doing Business 2014, World Bank, Washington, D.C

World Bank (2014b). Private Participation in Infrastructure Database.

World Bank (2012), Indian Economic Update September 2012, Washington, DC.

World Bank (2009), Doing Business 2009, World Bank, Washington, D.C 


\section{WORKING PAPERS}

The full series of Economics Department Working Papers can be consulted at www.oecd.org/eco/workingpapers

1182. The heterogeneity of product market regulations

(December 2014) by Jean-Marc Fournier

1181. Implicit regulatory barriers in the EU single market: new empirical evidence from gravity models

(December 2014) by Jean-Marc Fournier, Aurore Domps, Yaëlle Gorin, Xavier Guillet and Délia Morchoisne

1180. Can pro-growth policies lift all boats? An analysis based on household disposable income (December 2014) by Orsetta Causa, Alain de Serres and Nicolas Ruiz

1179. Empirical evidence on the effects of environmental policy stringency on productivity growth (December 2014) by Silvia Albrizio, Tomasz Koźluk and Vera Zipperer

1178. The Indicators of the Economic Burdens of Environmental Policy Design - Results from the OECD Questionnaire

(December 2014) by Tomasz Koźluk

1177. Measuring Environmental Policy Stringency in OECD Countries-A Composite Index Approach (December 2014) by Enrico Botta and Tomasz Koźluk

1176. Do Environmental Policies Matter for Productivity Growth? Insights from new Cross-Country Measures of Environmental Policies

(December 2014) by Silvia Albrizio, Enrico Botta, Tomasz Koźluk and Vera Zipperer

1175. Making economic growth more socially inclusive

(December 2014) by Andrés Fuentes Hutfilter and Andreas Kappeler

1174. New tax and expenditure elasticity estimates for EU budget surveillance

(December 2014) by Robert W.R. Price, Thai-Thanh Dang and Yvan Guillemette

1173. Moving towards a more dynamic business sector in Spain

(November 2014) by Alberto Gonzalez Pandiella

1172. Better harnessing talent and knowledge to boost sustainable medium-growth in Spain (November 2014) by David Haugh and Ben Westmore

1171. The internet economy - regulatory challenges and practices

(November 2014) by Isabell Koske, Rosamaria Bitetti, Isabelle Wanner and Ewan Sutherland

1170. A revival of the private rental sector of the housing market? Lessons from Germany, Finland, the Czech Republic and the Netherlands

(October 2014) by Rik de Boer and Rosamaria Bitetti

1169. Secular stagnation: evidence and implications for economic policy

(October 2014) by Łukasz Rawdanowicz, Romain Bouis, Kei-Ichiro Inaba and

Ane Kathrine Christensen 
1168. Investment gaps after the crisis

(October 2014) by Christine Lewis, Nigel Pain, Jan Strasky and Fusako Menkyna

1167. Factors behind the decline in real long-term government bond yield

(October 2014) by Romain Bouis, Kei-Ichiro Inaba, Łukasz Rawdanowicz and

Ane Kathrine Christensen

1166. The effect of the global financial crisis on the OECD potential output

(October 2014) by Patrice Ollivaud and David Turner

1165. Determinants of households' investment in energy efficiency and renewables - evidence from the OECD Survey on household environmental behaviour and attitudes

(October 2014) by Nadia Ameli and Nicola Brandt

1164. Addressing high household debt in Korea

(September 2014) by Randall S. Jones and Myungkyoo Kim

1163. Reducing the high rate of poverty among the elderly in Korea

(September 2014) by Randall S. Jones and Satoshi Urasawa

1162. Promoting the financing of SMEs and start-ups in Korea

(September 2014) by Randall S. Jones and Myungkyoo Kim

1161. Fostering inclusive growth by promoting structural change in the business sector

(September 2014) by Rauf Gönenç, Oliver Röhn, Vincent Koen and Fethi Öğünç

1160. Reducing macroeconomic imbalances in Turkey

(September 2014) by Oliver Röhn, Rauf Gönenç, Vincent Koen and Evren Erdoğan Coşar

1159. Reinvigorating the EU Single Market

(September 2014) by Jean-Marc Fournier.

1158. An exploration of the determinants of the subjective well-being of Americans during the great recession

(August 2014) by Aida Caldera Sánchez and Caroline Tassot.

1157. Boosting the development of efficient SMEs in the Netherlands

(September) by Rafał Kierzenkowski and Jochebed Kastaneer

1156. Making the banking sector more resilient and reducing household debt in the Netherlands

(September 2014) by Rafał Kierzenkowski, Olena Havrylchyk and Pierre Beynet

1155. US long term interest rates and capital flows to emerging economies

(July 2014) by Eduardo Olaberria

1154. Productivity measurement with natural capital and bad outputs

(July 2014) by Nicola Brandt, Paul Schreyer and Vera Zipperer

1153. Reducing income inequality and poverty and promoting social mobility in Korea

(July 2014) by Randall S. Jones and Satoshi Urasawa 